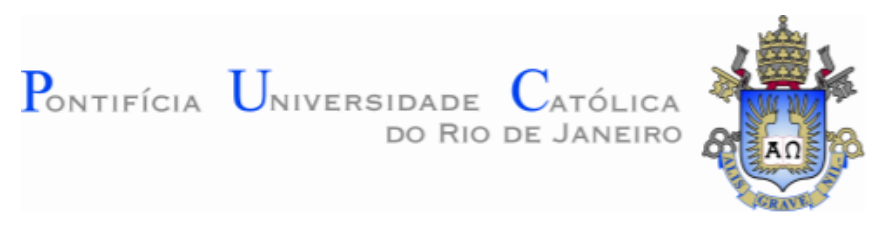

Rodrigo da Rocha Gomes

\title{
Decisões de Estrutura de Capital e Risco Idiossincrático
}

Dissertação de Mestrado

Dissertação apresentada como requisito parcial para a obtenção do grau de Mestre pelo Programa de PósGraduação em Macroeconomia e Finanças do Departamento de Economia do Centro de Ciências Sociais da PUC-Rio.

Orientador: Prof. Walter Novaes Filho

Rio de Janeiro Março de 2020 


\section{Rodrigo da Rocha Gomes}

\section{Decisões de Estrutura de Capital e Risco Idiossincrático}

Dissertação apresentada como requisito parcial para a obtenção do grau de Mestre pelo Programa de Pós-Graduação em Macroeconomia e Finanças do Departamento de Economia do Centro de Ciências Sociais da PUC-Rio. Aprovada pela Comissão Examinadora abaixo.

Prof. Walter Novaes Filho

Orientador

Departamento de Economia - PUC-Rio

Prof. Alexandre Lowenkron

Departamento de Economia - PUC-Rio

Prof. Márcio Gomes Pinto Garcia

Departamento de Economia - PUC-Rio

Rio de Janeiro, 31 de Março de 2020 
Todos os direitos reservados. É proibida a reprodução total ou parcial do trabalho sem autorização da universidade, da autora e do orientador.

\section{Rodrigo da Rocha Gomes}

Graduou-se com dupla diplomação em Engenharia de Produção na Escola Politécnica da Universidade Federal do Rio de Janeiro (POLI-UFRJ) e Ingénieur Généraliste pela École Centrale de Nantes em 2014

Ficha Catalográfica

Gomes, Rodrigo da Rocha

Decisões de estrutura de capital e risco idiossincrático / Rodrigo da Rocha Gomes ; orientador: Walter Novaes Filho. 2020.

49 f. : il. ; $30 \mathrm{~cm}$

Dissertação (mestrado)-Pontifícia Universidade Católica do Rio de Janeiro, Departamento de Economia, 2020.

Inclui bibliografia

1. Economia - Teses. 2. Estrutura de capital. 3. Retorno anormal. 4. Risco idiossincrático. 5. Aversão ao risco. 6. Participação acionária do governo. I. Novaes Filho, Walter. II. Pontifícia Universidade Católica do Rio de Janeiro. Departamento de Economia. III. Título.

CDD: 330 


\section{Agradecimentos}

Agradeço à minha família, à Lojas Americanas pela oportunidade, ao meu orientador Walter Novaes, aos professores da banca avaliadora, aos professores e funcionários do departamento de Economia da PUC-Rio e à turma de mestrado profissional de 2017. 


\section{Resumo}

Gomes, Rodrigo da Rocha; Novaes Filho, Walter. Decisões de estrutura de capital e risco idiossincrático. Rio de Janeiro, 2020. 49p. Dissertação de Mestrado - Departamento de Economia, Pontifícia Universidade Católica do Rio de Janeiro.

Estratégias de diversificação de riqueza têm como objetivo eliminar o risco idiossincrático. Estas estratégias não estão disponíveis para acionistas controladores em empresas como no Brasil, em que o controle tem grande valor e os controladores não querem correr o risco de abrir mão dele, como visto por Leal et al (2002). Nesse contexto, risco idiossincrático deve ser relevante para decisões de endividamento corporativo. Para testar esta hipótese, é coletada uma amostra de 329 empresas de capital aberto da B3 de 2003 a 2017. Regressões com variáveis instrumentais mostram que 1 desvio padrão de variação do risco idiossincrático impacta em uma redução de endividamento de 0,18 desvio padrão. Esta relação não é encontrada para empresas controladas pelo governo. Concentração de propriedade, portanto, magnifica problemas de financiamento e alocação de capital em empresas privadas.

\section{Palavras-chave}

Estrutura de capital; Retorno anormal; Risco idiossincrático; Aversão ao risco; Participação acionária do governo. 


\section{Abstract}

Gomes, Rodrigo da Rocha; Novaes Filho, Walter (Advisor). Capital structure choice and idiosyncratic risk. Rio de Janeiro, 2020. 49p. Dissertação de Mestrado - Departamento de Economia, Pontifícia Universidade Católica do Rio de Janeiro.

Wealth diversification strategies aim to eliminate idiosyncratic risk. Those strategies are not available for controlling shareholders in companies like in Brazil, where control is highly valued, and shareholders don't want to risk losing it, as seen in Leal et al (2002). In this context, idiosyncratic risk should be relevant for capital structure decision making. To test this hypothesis, a sample of 329 private firms in B3 from 2003 to 2017 is used. Regressions with instrumental variables show that 1 standard deviation change in idiosyncratic risk impacts in a reduction in leverage of 0.18 standard deviations. This relation is not found among government-controlled firms. Thus, propriety concentration magnifies financing problems and capital allocation in private firms.

\section{Keywords}

Capital structure; Abnormal returns; Idiosyncratic risk; Risk aversion; Government equity; Brazilian companies. 


\section{Sumário}

$\begin{array}{ll}\text { 1. Introdução } & 10\end{array}$

2. Revisão da Literatura 15

$\begin{array}{ll}3 . & 19\end{array}$

4. Seleção da Amostra e Estatísticas Descritivas 23

5. Resultados das Regressões de Estrutura de Capital 27

6. Análise de Robustez 29

$\begin{array}{ll}\text { 7. Conclusão } & 37\end{array}$

8. Referências bibliográficas 39

9. Apêndice 41

10. Tabelas 42 


\section{Lista de Figuras}

Figura 1: Evolução do endividamento total 24

Figura 2: Evolução da volatilidade total e idiossincrática 25

Figura 3: Estratificação da Vol Idiossincrática pelo Valor de Mercado 26

Figura 4: Volatilidade EBIT no tempo 26

Figura 5: Volatilidades no tempo 32

Figura 6: Dívida sobre ativo total e das firmas do governo 34

Figura 7: Evolução da volatilidade idiossincrática 35

Figura 8: Participação de firmas do governo 35

Figura 9: Evolução do valor de mercado de firmas do governo 36 


\section{Lista de Tabelas}

Tabela 1: Dados de balanço para análise da estrutura de capital 42

Tabela 2: Amostra de empresas por setor 43

Tabela 3: Dados de volatilidades idiossincráticas e sistêmicas 44

Tabela 4: Regressões da estrutura de capital 45

Tabela 5: Regressão variando volatilidade idiossincrática 46

Tabela 6: Firmas classificadas "Estatal Majoritário" ou "Participação" 47

Tabela 7: Comparação da alavancagem por tipo de firma 48

Tabela 8: Regressão da estrutura de capital com dummy de governo 49 


\section{1. \\ Introdução}

Desde Modigliani e Miller (1958), as teorias modernas de apreçamento de ativos financeiros e de alocação de riqueza se desenvolveram ao redor de um princípio básico: risco idiossincrático não afeta os retornos esperados de equilíbrio porque estratégias de diversificação de ativos podem eliminar riscos idiossincráticos sem incorrer em custos econômicos relevantes. A despeito do papel central do princípio de diversificação, Goyal e Santa Clara (2001) encontram uma relação positiva entre risco idiossincrático e retornos esperados em uma amostra de 437 retornos mensais de ações americanas entre 1963 e 1999. Goyal e Santa Clara (2001) interpretam seus resultados como evidência de fricções de mercado que dificultam a diversificação do risco e impõem limites para arbitragem. ${ }^{1}$

Existindo fricções na formação de estratégias de diversificação é de se esperar que elas também afetem decisões corporativas que extrapolem a alocação de recursos entre ativos financeiros. O endividamento de empresas cujo controle acionário esteja concentrado em poucos investidores, por exemplo, deveria variar com a importância do risco idiossincrático no fluxo de caixa. A concentração acionária impede que o risco idiossincrático seja diversificado e, então, o controlador diminui o endividamento para reduzir o risco idiossincrático, enquanto os demais acionistas lidam com o risco idiossincrático ajustando suas carteiras de investimento. Quanto maior for a importância desse risco idiossincrático, menos propensos os controladores devem estar para se endividar fortemente. Testar essa hipótese é o objetivo principal desta dissertação.

Para testar a hipótese que associa risco idiossincrático ao endividamento corporativo, três ingredientes principais são necessários. O primeiro é uma medida de risco idiossincrático relevante para a decisão de endividamento. Para obter essa medida, partimos do trabalho seminal de Goyal e Santa Clara (2001). De maneira

\footnotetext{
1 A interpretação de Goyal e Santa Clara (2001) para o coeficiente significativo do risco idiossincrático nas regressões deles não é consensual entre os pesquisadores de Finanças. Angelides e Tessaromatis (2006), por exemplo, argumentam que a dita relevância do risco idiossincrático se deve às empresas pequenas ilíquidas na amostra utilizada pelos autores.
} 
sucinta, esses autores estimam o risco idiossincrático dos retornos das ações calculando as variâncias dos resíduos dos retornos diários de um modelo de mercado. As médias mensais das variâncias desses resíduos são a estimativa dos autores para o risco idiossincrático da carteira de ações. Seguindo essa metodologia, calculamos as variâncias mensais dos resíduos dos retornos diários das ações de cada empresas na amostra e consideramos para cada ano as médias das variâncias mensais para obter uma proxy do risco idiossincrático no modelo de endividamento com frequência anual.

O segundo ingrediente básico da dissertação é uma amostra de endividamento de empresas com estrutura de propriedade concentrada em poucos investidores. La Porta e Shleifer (1999) é um bom guia para tal amostra; eles mostram que empresas com concentração de estrutura de propriedade estão tipicamente presentes em países com sistema jurídico na família do Direito Civil Francês - o Brasil sendo um desses países. De fato, Leal et al. (2002) encontram uma estrutura acionária concentrada no Brasil, justificando a amostra desta dissertação: um painel de 329 empresas com ações listadas na B3, com dados entre 2003 e 2017, totalizando 2.873 observações. Nessa amostra a média do endividamento bancário sobre ativos foi de $25 \%$ nos anos de maior crescimento econômico (até 2008) e $28 \%$ nos anos seguintes de menor crescimento. O risco idiossincrático, como definido anteriormente por Goyal e Santa Clara (2001), apresentou média de 23\% durante a fase de maior crescimento e de $17 \%$ na fase de menor crescimento.

O terceiro ingrediente é a especificação de um modelo empírico que associe endividamento ao risco idiossincrático e que leve em conta os problemas inerentes a estimação de modelos de forma reduzida, mais especificamente a omissão de variáveis não observadas e a causalidade reversa. Não há inovação na seleção do momento; ele parte da especificação proposta por Rajan e Zingales (1995) e inclui a medida de risco da volatilidade idiossincrática como definida por Goyal e Santa Clara (2001).

Na especificação proposta para o modelo de endividamento, o principal candidato para omissão de variável é a aversão ao risco do controlador que, quase certamente, 
varia entre as empresas da amostra. Lemmon, Roberts e Zender (2008) mostram como controlar variáveis que devem mudar pouco no tempo, como a aversão ao risco, em regressões de endividamento: basta introduzir efeitos fixos de empresa. ${ }^{2}$ Efeitos fixo de empresas são então introduzidos no modelo básico de endividamento. Ainda assim, um segundo problema de endogeneidade causalidade reversa - mina a confiabilidade de testes baseados em regressões de endividamento com efeitos fixos de empresa.

Sob a hipótese de fricções para diversificação, é de se esperar que elevado risco idiossincrático eventualmente gere prejuízos que aumentam a necessidade de financiamento enquanto lucros elevados esporádicos induzam os controladores a pagar mais dividendos para reduzir o impacto do risco idiossincrático no bem-estar do grupo controlador. Ora, a combinação de aumento de endividamento em resposta a prejuízos extraordinários e aumento de dividendos em reposta a lucros extraordinários gera uma correlação positiva espúria na regressão de efeitos fixos do endividamento; essa correlação espúria dificulta a interpretação dos testes.

Para eliminar a regressão espúria, precisa-se de um instrumento correlacionado com o risco idiossincrático da empresa, mas que só seja correlacionado com a decisão de endividamento pelo risco idiossincrático. Nesta dissertação, o instrumento proposto é o risco idiossincrático da indústria em que a empresa está inserida. Por um lado, fatores comuns a fricções nas empresas em uma mesma indústria sugerem que o risco idiossincrático não diversificável de uma empresa esteja correlacionado com o risco idiossincrático não diversificável da indústria. Por outro lado, lucros extraordinários e prejuízos extraordinários para a indústria como um todo são menos prováveis de ditar as decisões de financiamento e pagamento de dividendo das empresas dentro da indústria, levando-se em conta os controles usuais das regressões de endividamento.

\footnotetext{
${ }^{2}$ Lemmon, Robert e Zender (2008) coletam dados entre empresas e ao longo do tempo, introduzindo os controles tradicionais da literatura de estrutura de capital (tamanho, lucratividade, proporção de ativos permanente sobre ativos totais e oportunidade de crescimento, já presentes nos modelos propostos por Rajan e Zingales (1995)), além de efeitos fixos de empresas.
} 
Sem o instrumento, a regressão de efeitos fixos do endividamento apresenta um coeficiente de -0,068 para o risco idiossincrático; esse coeficiente não é estatisticamente significativo a 5\% (p-valor de 0,062) e sua relevância econômica é pequena: um aumento no risco idiossincrático de 1 desvio padrão (11\%) reduz o endividamento em 0,04 desvio padrão $(0,75 \%)$. Na estimação em que os riscos idiossincráticos das empresas são instrumentalizados pelos riscos idiossincráticos das indústrias, o coeficiente do risco idiossincrático é estatisticamente significativo a $1 \%$ (p-valor de 0,002 ) e -0,279 e é relevante em termos econômicos: coeficiente estimado de -0,270 implica que um aumento de 1 desvio padrão no risco idiossincrático (11\%) reduz o endividamento em 0,180 desvio padrão $(3,1 \%)$. Esse efeito é 4,1 vezes maior do que o da regressão estimada sem o instrumento. O aumento do valor absoluto do coeficiente estimado por variáveis instrumentais sugere a seguinte causalidade reversa: a elevação do endividamento implica em um aumento do risco idiossincrático, confundindo os incentivos do aumento do risco idiossincrático para a redução do endividamento.

Para aumentar a confiança na interpretação da estimação por variáveis instrumentais, introduzimos nas variáveis independentes a interação do risco idiossincrático com a dummy de empresa controlada pelo governo (ou que tenham o governo como um dos controladores). Em tese, o governo deve ser menos sensível ao risco idiossincrático que investidores privados. Sendo assim, espera-se que o coeficiente da interação da dummy de governo com o risco idiossincrático seja positivo, refletindo um efeito causal menos expressivo do risco idiossincrático das empresas governamentais. Como esperado, o coeficiente encontrado para a interação de interesse foi positivo: 0.301 (p-valor de 0.156). E o efeito total do risco idiossincrático para firmas do governo é estatisticamente indistinguível de zero (p-valor de 0.999) e sem relevância econômica. A análise de firmas do governo mostra, portanto, consistência com o fato do agente público ser menos sensível ao risco.

O restante deste trabalho está dividido em 7 seções. Após a seção introdutória, a segunda apresenta uma revisão da literatura sobre trabalhos relacionados a risco idiossincrático e estrutura de capital. A terceira seção apresenta a metodologia para 
cálculo do risco idiossincrático e o modelo empírico de endividamento corporativo, com a quarta seção discutindo a seleção da amostra e apresentado estatísticas descritivas. A quinta seção apresenta os resultados empíricos principais, com a análise de robustez aparecendo na sexta seção. A sétima seção conclui a dissertação. 


\section{2. \\ Revisão da Literatura}

Esta seção está organizada em duas partes. A primeira é dedicada a trabalhos sobre os determinantes do endividamento das firmas no âmbito internacional. A segunda parte, por sua vez, se concentra na literatura sobre risco idiossincrático.

\section{1}

\section{Determinantes do Endividamento das Firmas}

A discussão sobre os principais fatores que determinam a estrutura de capital das empresas se mostra presente em Modigliani e Miller (1958), onde são lançadas as premissas da irrelevância da alavancagem para o valor da firma.

Tendo à disposição bases de dados históricas de decisões de investimento, pesquisadores começam a quantificar o impacto das características das firmas no seu nível de endividamento. Como exemplo cita-se Rajan e Zingales (1995) que analisam os fatores determinantes da estrutura de capital para os países do G7 (Estados Unidos, Japão, Alemanha, França, Itália, Inglaterra e Canadá) no período de 1987 a 1991. Os fatores relevantes encontrados foram tangibilidade (+), tamanho (+), rentabilidade (-) e crescimento (-).

Em trabalhos mais recentes são explorados os efeitos fixos de firmas, risco, indústria e macroeconômicos. Tem-se como exemplo os trabalhos de Frank e Goyal (2008), Lemmon, Robert e Zender (2008), Kayo e Kimura (2011) e Graham, Leary e Robert (2015).

No Brasil os estudos são mais recentes e dão destaque para amostras nacionais menores e menos diversificadas do que a internacional. Ainda, segundo Gomes e Leal (2001), juros elevados e ausência de financiamento de longo prazo são evocados como razões para o menor endividamento das grandes empresas e uso intensivo de dívida de curto prazo pelas pequenas empresas. Este fato é corroborado por Mota e Coelho (2014), que verificam um aumento do endividamento com a disponibilidade de financiamento de longo prazo. 


\section{2 \\ Volatilidade e Retornos idiossincráticos}

A volatilidade de retornos se mostra pertinente pela literatura para a tomada de decisão dos gestores pois verifica-se que aumentos de volatilidade dos fluxos de caixa da firma impactam na redução dos investimentos e aumento do custo da dívida, conforme Minton e Schrand (1999) mostram a partir de uma amostra de 1.135 empresas americanas da base Compustat de 1988 a 1995.

Campbell et al. (2001) também documentam, a partir de uma amostra de 8.927 firmas americanas do Center for Research in Security Prices (CRSP) de 1962 a 1997, que a volatilidade das firmas é maior do que a volatilidade do mercado em si, e que cada vez precisamos de mais ativos para atingir um mesmo nível de diversificação dos riscos específicos das firmas.

Com o aumento da significância destes riscos específicos das firmas, denominado risco idiossincrático, surge a necessidade do estudo das particularidades dele, bem como de isolá-lo do risco sistêmico. Neste contexto, Goyal e Santa-Clara (2001) analisam dados norte-americanos de 1962 a 2000, e estudam o efeito do risco idiossincrático no retorno das firmas. Encontram que tanto a volatilidade de alta frequência (diária) quanto a volatilidade de baixa frequência (mensal) apresentam efeito positivo nos retornos mensais dos ativos. Os autores realizam testes de robustez para small-sample bias e business cycle bias e constatam a persistência do efeito. Esta evidência reforça a hipótese de que os investidores não conseguem diversificar perfeitamente seus portfolios ${ }^{3}$, como visto por Malkiel e Xu (2002).

Por sua vez, Bali e Cakici (2005) criticam o trabalho de Goyal e Santa Clara (2001), reforçando que a medida da volatilidade idiossincrática deve usar pelo menos um modelo de mercado. Os autores relacionam o prêmio idiossincrático a firmas pequenas - também estudado por Angelidis e Tessaromatis (2006) - e à

\footnotetext{
${ }^{3}$ Segundo a teoria de finanças pelo modelo CAPM (Treynor (1962), Sharpe (1964), dentre outros) apenas o risco sistêmico é precificado. A teoria do risco idiossincrático vai de encontro a esta, afirmando que devido aos investidores não poderem balancear perfeitamente seus portfolios, carregam sempre algum risco idiossincrático e que, portanto, este seria precificado.
} 
falta de liquidez, e verificam que, com uma amostra estendida de 1963 a 2001, o efeito se torna insignificante.

Parte da falta de consenso sobre o sinal do efeito do risco idiossincrático pode ser explicado por trabalhos recentes como o de Fu (2009) e Bégin, Dorien e Gauthier (2018). Ambos verificam tanto a variação quanto a persistência do risco idiossincrático no tempo através de modelos $\mathrm{EGARCH}^{4}$ e contestam o sinal negativo encontrado para a relação com o retorno presente na literatura até então.

No Brasil, Galdi e Securato (2007) estudam se o risco idiossincrático é relevante no mercado brasileiro em uma base de 1999 a 2006, seguindo as metodologias de Goyal e Santa Clara (2001). A amostra consiste das 15 ações mais negociadas no período e os autores não encontram efeitos significativos dos riscos sistêmicos ou idiossincráticos nos retornos das firmas, porém concordam que um aumento do período amostral e/ou do número de firmas poderia alterar os resultados observados.

Neto et al. (2018), por sua vez, estudam os determinantes da volatilidade idiossincrática no mercado brasileiro, em uma amostra de 2011 a 2016, aplicando o modelo de 5 fatores de Carhart (1997) para definição do risco, e encontram endividamento, índice book-to-market e retorno sobre ativos como variáveis significantes. Em especial, o endividamento apresenta coeficiente positivo, e em determinados quantis de empresas as variáveis de tamanho e liquidez também foram relevantes.

Em resumo, os estudos sobre volatilidade idiossincrática tratam apenas da relação com retornos ou, no máximo, tentam explicar a volatilidade idiossincrática com dados de características das firmas. O caso brasileiro já apresenta alguns estudos sobre risco idiossincrático e, assim como na literatura internacional, dependendo da amostra de firmas e período selecionado os resultados não apresentam consenso sobre o efeito do risco sobre os retornos.

\footnotetext{
4 Modelo de heteroscedasticidade condicional auto-regressiva generalizada exponencial (EGARCH), introduzido por Nelson (1991).
} 
Finalmente, não foram encontrados na literatura até o momento quaisquer artigos que relacionem o endividamento ao risco idiossincrático como fator explicativo, bem como exemplos nos quais o viés de causalidade reversa tenha sido endereçado - ambos objeto de análise no atual estudo. 


\section{3. \\ Metodologia do estudo}

Esta seção descreve o modelo empírico usado para testar a relevância do risco idiossincrático nas decisões de endividamento corporativo.

O modelo de estrutura de capital desta dissertação segue de perto a especificação de Rajan e Zingales (1995) com a inclusão de efeitos fixos de empresas, conforme proposto por Lemmon, Roberts e Zender (2008). A equação (1) apresenta essa especificação, incluindo a variável independente de interesse principal, ou seja, o risco idiossincrático da empresa. A regressão usa dados anuais entre 2003 e 2017, sendo o risco idiossincrático da empresa i no ano $\mathrm{t}$ - denotado por Volid $_{i t}$ - uma média dos riscos idiossincráticos da empresa i nos doze meses do ano t.

$\frac{\text { DivBruta }}{\text { Ativo }}_{\text {it }}=b_{1} \frac{\text { AtivoFixo }}{\text { Ativo }}_{i(t-1)}+b_{2} \log (\text { Vendas })_{i(t-1)}+b_{3}{\frac{\text { EBIT }}{\text { AtivoTotal }_{i}(t-1)}}_{+}+$

$b_{4} \frac{\text { ValMercAtivos }}{\text { Ativo }}_{i(t-1)}+b_{5} D_{\text {cresc } t}+b_{6} \operatorname{Volid}_{i(t-1)}+b_{7} \operatorname{VolEbit}_{i(t-1)}+\mu_{i}+\varepsilon_{i t}$

As quatro primeiras variáveis independentes na equação (1), defasadas para t-1 com relação ao endividamento, são as usuais dos estudos empíricos sobre endividamento corporativo. Espera-se que empresas com mais ativos fixos tenham mais facilidade em oferecer garantias reais, expandindo a capacidade de endividamento ( $b_{1}$ positivo). Na mesma linha, empresas maiores (parametrizadas pelo log do montante em reais de suas vendas) tipicamente têm mais acesso a instrumentos financeiros que reduzem risco financeiro e aumentam a capacidade de endividamento ( $b_{2}$ positivo), enquanto valores maiores do Q-Tobin ${ }^{5}$ sugerem oportunidades de investimento mais fortes e maiores custos de estresse financeiro ( $b_{4}$ negativo). Conforme Myers-Majluf (1984) argumentam, problemas de seleção adversa sugerem uma relação negativa entre endividamento e lucratividade $\left(b_{3}\right.$ negativo).

\footnotetext{
${ }^{5}$ Valor de mercado dos ativos sobre ativos, introduzido por Kaldor (1966).
} 
Já o coeficiente do desvio-padrão do EBIT sobre o Ativo Total é um controle usual do risco do fluxo de caixa da empresa, que gera preocupações de estresse financeiro e reduz os incentivos para a empresa se endividar ( $b_{7}$ negativo). Esse desvio padrão é estimado em cada ano pelo desvio quadrático médio do EBIT sobre o Ativo Total em relação à média da amostra total, começando com uma única observação em 2003 e incrementando uma nova observação do desvio quadrático, conforme a especificação na equação (2). Além desses controles, a regressão inclui uma dummy para a divisão dos anos de maior/menor crescimento e efeitos fixos de empresa.

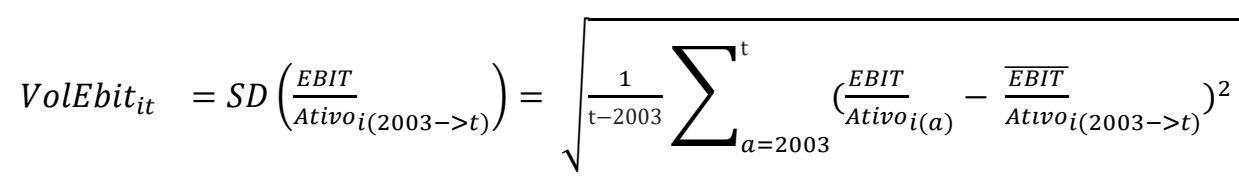

O risco idiossincrático da empresa $\left(\right.$ Volid $\left._{i t}\right)$ é calculado seguindo a metodologia de Goyal e Santa Clara (2001). O ponto de partida para esse cálculo é a equação (3), que calcula o resíduo do retorno diário de cada ação na amostra do modelo de mercado:

$r_{i d}=\alpha_{i}+\beta_{i m} *\left(r_{m d}-r_{f d}\right)+r_{f d}+\varepsilon_{l d}^{\cdot}$

A equação (3) é estimada em cada data d, usando os 60 retornos anteriores. $\mathrm{O}$ prêmio de risco de mercado $\left(r_{m d}-r_{f d}\right)$ é calculado pela base NEFIN-USP usando o retorno do IBOVESPA na data d como retorno de mercado $\left(r_{m d}\right)$ e a taxa DI como taxa livre de risco na data d $\left(r_{f d}\right)^{6}$. Ainda, na equação (3), o alfa de Jensen é representado por $\left(\alpha_{i}\right)$ e o resíduo do modelo $\left(\varepsilon_{l d}\right)$ é utilizado para o cálculo do risco idiossincrático ${ }^{7}$.

\footnotetext{
${ }^{6} \mathrm{O}$ site http://www.nefin.com.br/Metodologia/Risk Factors/Market Factor.txt apresenta a metodologia e dados disponibilizados pelo NEFIN-USP para estimar o modelo de mercado na equação (3).

${ }^{7}$ Alfas positivos significam retornos anormais acima do precificado pelo mercado e alfas negativos seriam retornos anormais abaixo do esperado pelo mercado.
} 
Obtidos os resíduos $\varepsilon_{i d}$ da equação (3) para cada ação i em cada data d, a equação (4) calcula o desvio padrão do resíduo dos retornos diários em um intervalo de 20 dias úteis em cada mês na amostra para então multiplicar por $\sqrt{20}$ e obter o risco idiossincrático do mês m no ano t, $\operatorname{Volid}_{i t(m)}$. Desse risco idiossincrático tomase a média dos 12 meses do respectivo ano na equação (5) para o cálculo do Volid $_{i t}$, ou seja, risco idiossincrático do ano t.

$$
\begin{aligned}
& \operatorname{Volid}_{i t(m)}=\sqrt{20} * S D\left(\dot{\varepsilon}_{i d}\right)=\sqrt{20} * \sqrt{\frac{1}{20} \sum_{d=1}^{20}\left(\dot{\varepsilon}_{i d}-\dot{\bar{\varepsilon}}_{l}\right)^{2}} \\
& \operatorname{Volidi}_{i t}=\frac{1}{12} \sum_{m=1}^{12} \operatorname{Volid}_{i t(m)}
\end{aligned}
$$

A volatilidade de mercado também é calculada de forma análoga, conforme apresentam as equações (6) e (7), com a mesma periodicidade do risco idiossincrático para efeito de comparabilidade.

$$
\begin{aligned}
& V_{m t(m)}=\sqrt{20} * S D\left(r_{m d}\right)=\sqrt{20} * \sqrt{\frac{1}{20} \sum_{d=1}^{20}\left(r_{m d}-\bar{r}_{m}\right)^{2}} \\
& V_{m t}=\frac{1}{12} \sum_{m=1}^{12} V_{m t(m)}
\end{aligned}
$$

Neste trabalho, as volatilidades das ações são instrumentalizadas pelas volatilidades das indústrias em que estão inseridas de forma a eliminar problemas de causalidade reversa na regressão do endividamento. A validade do instrumento se apoia em dois argumentos. Primeiro, as fricções comuns a empresas na indústria sugerem que o risco idiossincrático da indústria seja correlacionado com o risco idiossincrático das empresas. Segundo, a volatilidade idiossincrática é suavizada ao agregarmos o fluxo de caixa das empresas em uma mesma indústria, amenizando a correlação positiva entre endividamento e retorno idiossincrático negativo, bem como a correlação positiva entre pagamento de dividendos e retorno idiossincrático positivo. 
Nas estimações por variáveis instrumentais, a volatilidade idiossincrática da indústria da firma i é a média das volatilidades das $\mathrm{N}$ firmas para cada umas das $\mathrm{K}$ indústrias para o dado ano t, conforme descrita na equação (8):

Volid $_{\text {indt }}=\frac{1}{\text { Nsetor }} \sum_{i=1}^{K}$ Volid $_{i t}$

A hipótese a ser testada é se o risco idiossincrático é relevante para as decisões de endividamento, ou seja:

$$
\begin{aligned}
& H_{0}^{1}: b_{6}=0 \\
& H_{1}^{1}: b_{6} \neq 0
\end{aligned}
$$




\section{4. Seleção da Amostra e Estatísticas Descritivas}

O ponto de partida da amostra são todas a empresas de capital aberto com ações listadas na B3 entre dezembro de 2003 e dezembro de 2017, sem impor a restrição de as empresas na amostra terem suas ações negociadas em todo o período. $\mathrm{Ou}$ seja, trata-se de um painel desbalanceado. O período amostral inclui anos de expansão da economia (2003 a 2008) e anos de menor crescimento (2009 a 2017). $\mathrm{O}$ ano de corte para os dois períodos é baseado na queda abrupta do valor de mercado das firmas de 2008 para 2009.

A amostra inicial inclui 531 empresas com valores de ativos totais disponíveis na Bloomberg, para um total de 7.329 empresas-ano. Após a exclusão das observações com patrimônio líquido negativo, a amostra diminui para 510 empresas e 6.432 empresas-ano. Removendo as empresas do setor financeiro, devido a sua particularidade da relação entre dívida e ativos reconhecida por Rajan e Zingales (1995), chega-se a um total de 329 empresas no período. Por fim, restringimos a amostra para as 2.873 empresas-ano com informações de dívida bruta sobre ativos, vendas líquidas, EBIT, ativos fixos e valor de mercado dos ativos. Para evitar outliers e erros de medidas, as caudas das variáveis usadas dessas empresas foram substituídas pelos seus valores no percentil 1 e no percentil 99 da amostra final.

\section{1}

\section{Dados financeiros}

A variável que representa o endividamento é a dívida bruta que paga juros (debêntures e empréstimos bancários de curto e longo prazo) sobre o total dos ativos. As principais variáveis explicativas são: (i) o tamanho, medido pelo log das vendas líquidas; (ii) a lucratividade operacional, medida pelo EBIT sobre total ativos; (iii) o grau de tangibilidade pelos ativos permanentes sobre ativos totais; e (iv) as oportunidades de crescimento, medidas pelo valor de mercado dos ativos pelo valor de balanço dos ativos. 
A tabela 1 mostra que não há grande discrepâncias entre os indicadores financeiros médios e medianos da amostra. Em particular, os endividamentos médio (27\%) e mediano (28\%) são similares aos valores encontrados por Rajan e Zingales (1995) para as empresas nos países do G7. Como esperado, as firmas da amostra são mais lucrativas e as oportunidades de investimento das empresas são maiores no período de expansão da economia brasileira (2003 a 2008). Por sua vez, no período de menor crescimento a proporção média dos ativos tangíveis das empresas reduziu, embora tenha sido mantida a participação relativa na amostra dos setores da economia.

A Figura 1 descreve a trajetória do endividamento no período amostral.

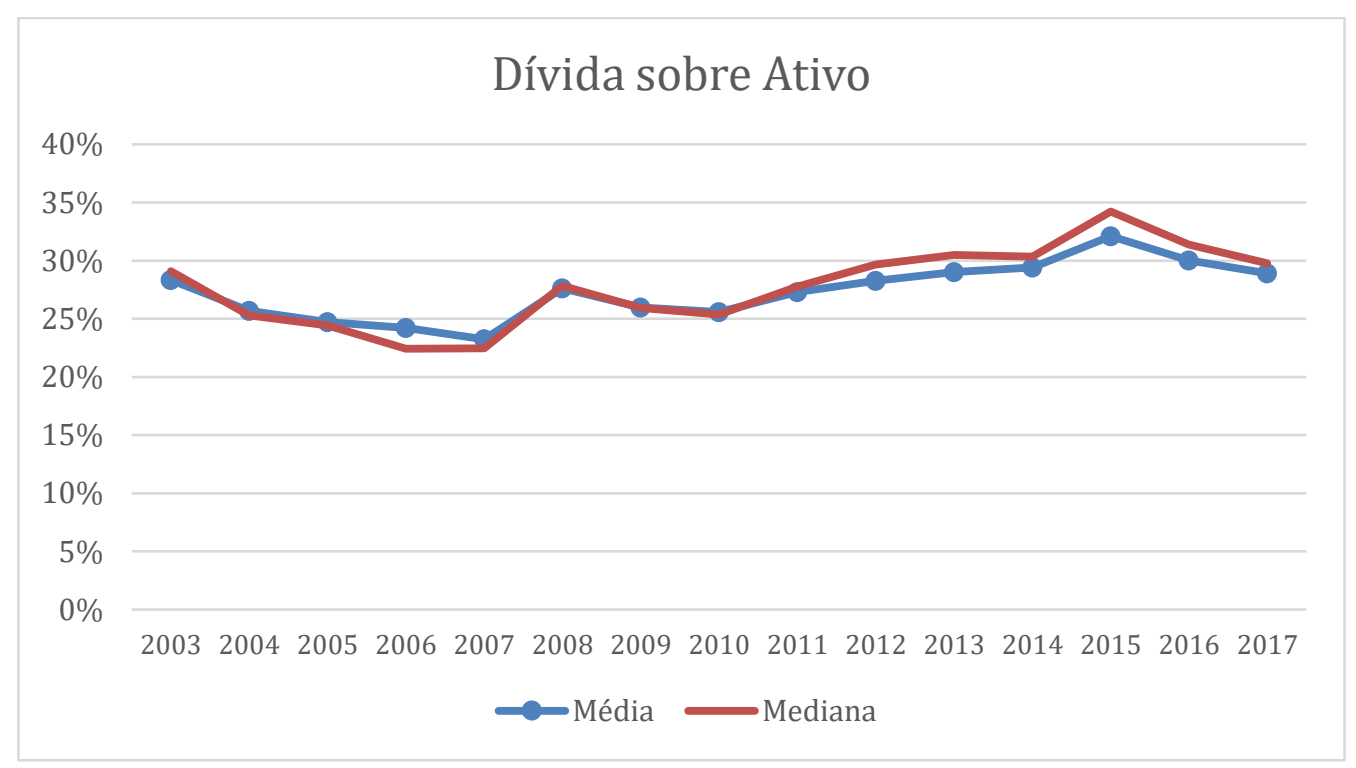

Figura 1 - Evolução do endividamento total

A tabela 2, por sua vez, descreve a distribuição das empresas e observações entre setores da indústria, conforme classificação da Bloomberg. Os setores com maior número de observações/empresas são os de Consumo cíclico (653), Consumo não cíclico (575) e Infraestrutura (511). Esses três setores predominaram ao longo de todo período amostral. 


\section{2 \\ Dados de retornos}

Das 329 firmas com dados de balanço disponíveis entre 2003 e 2017, encontramos dados de retornos diários na Bloomberg para 308 firmas, resultando em 28.218 empresas-mês. A partir dos dados de retornos, as volatidades idiossincráticas das empresas foram calculadas conforme as equações (2) a (8) e suas estatísticas descritivas são apresentadas tabela 3, que, para fins de comparação, também apresenta as estatísticas descritivas da volatilidade do retorno de mercado (IBOVESPA). Em particular, a volatilidade idiossincrática média é de $17 \%$ ao mês. Como esperado, a volatilidade média do mercado é bem menor: $7 \%$ ao mês.

A figura 2 mostra as trajetórias mensais das médias das volatilidades idiossincráticas das empresas e do mercado. A volatilidade média das empresas cai de 28\% no ano de 2003 para 12\% em 2007, uma queda quase monotônica. Em contraste, a volatilidade média do mercado permaneceu aproximadamente constante durante o período da amostra, excetuando o período de 2007 a 2008, quando subiu de $7,0 \%$ para $11,9 \%$, voltando depois ao patamar inicial. A figura 3 ilustra $o$ fato de empresas menores apresentarem maior volatilidade idiossincrática. A figura 4 mostra a evolução da volatilidade Ebit no tempo, de 2,5\% em 2004 a 4,6\% em 2017.

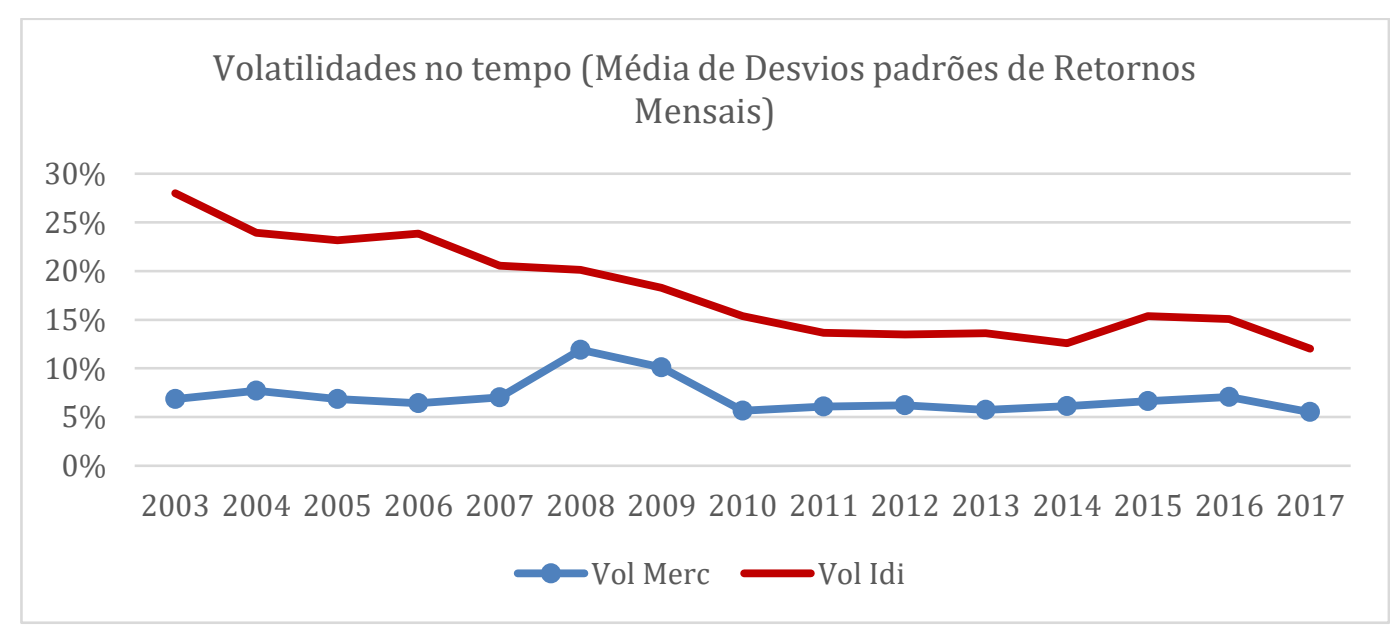

Figura 2 - Evolução das volatilidades total e idiossincrática 


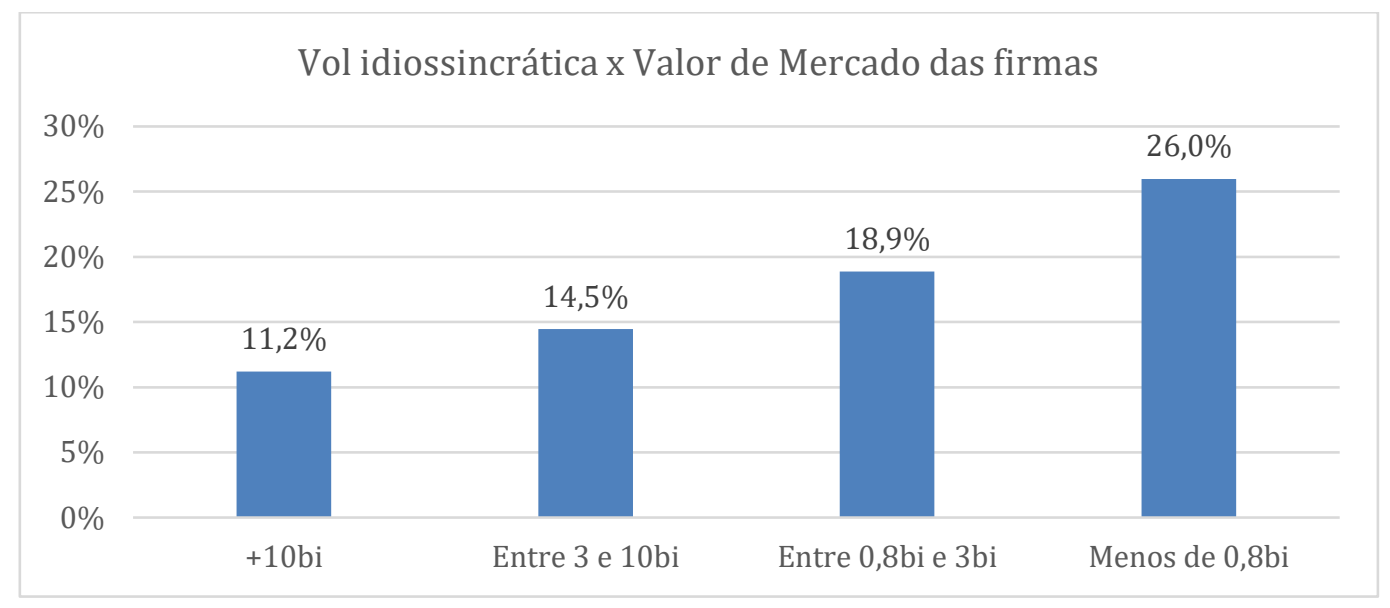

Figura 3 - Estratificação da Volatilidade Idiossincrática pelo Valor de Mercado das firmas

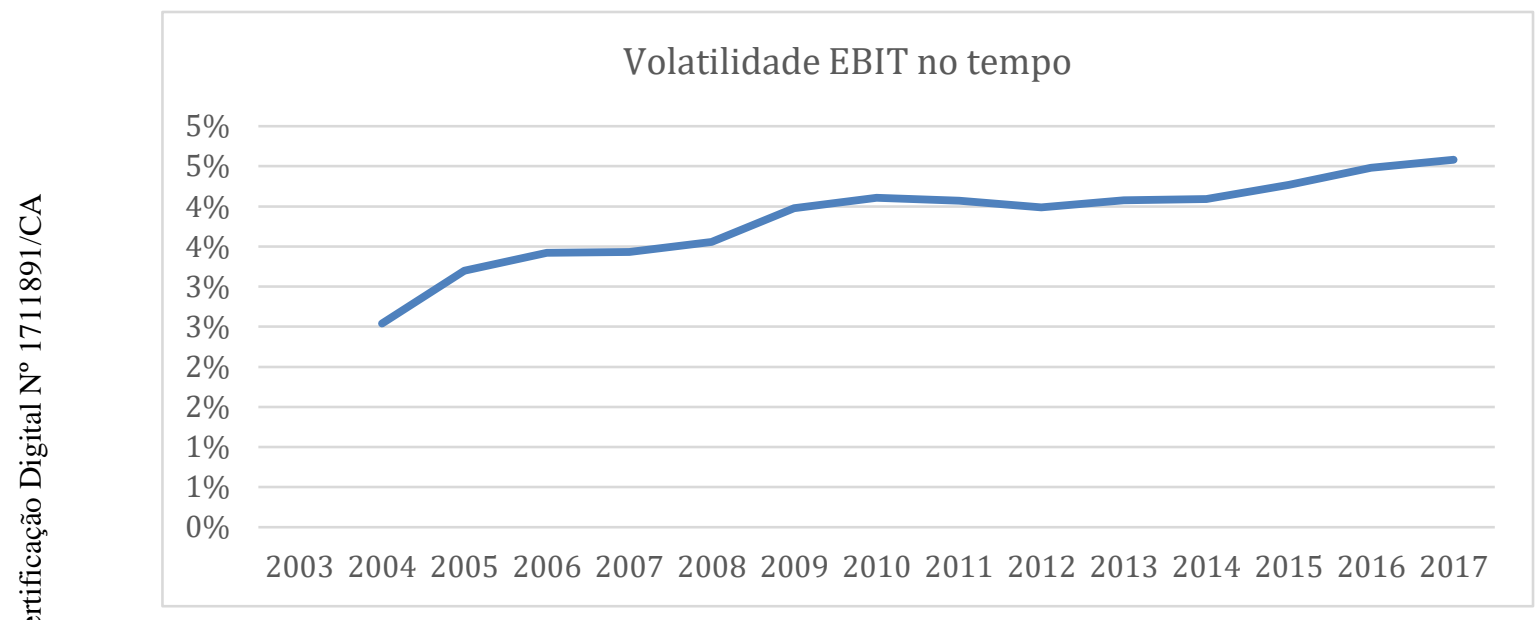

Figura 4 - Volatilidade EBIT no tempo 


\section{5. \\ Resultados das Regressões de Estrutura de Capital}

Esta seção estima os coeficientes da equação (1) que modela as decisões de endividamento das empresas na nossa amostra. As três primeiras colunas na tabela 4 estimam os coeficientes pelo método de mínimos quadráticos ordinários (MQO) com efeitos fixos de empresas e a quarta coluna instrumentaliza o risco idiossincrático das empresas pelo risco idiossincrático de suas indústrias para contornar problemas de causalidade reversa ${ }^{8}$.

$\mathrm{Na}$ tabela 4 observa-se que os sinais das variáveis tamanho (positivo) e lucratividade (negativo) são significativos a $1 \%$ e seguem os sinais esperados pela literatura, condizentes com os identificados por Rajan Zingales (1995) e Frank e Goyal (2008). Os fatores de tangibilidade e Q-Tobin não foram estatisticamente significativos em todas as regressões.

Em todas as estimações realizadas, um aumento do risco idiossincrático diminui o endividamento, como é de se esperar em um mercado com estrutura acionária concentrada e com fricções que dificultam a eliminação de risco idiossincrático. Existe, contudo, uma diferença entre as estimações por MQO e VI, pois a estimação não é significativa no MQO e é significativa com o instrumento: coeficiente $b_{6}$ de -0.068 (p-valor de 0.061) em MQO contra -0.279 (p-valor de 0.002 ) - suficiente para validar a hipótese 1 . No primeiro, o coeficiente de -0.068 implica em um impacto econômico não significante de 0,040 desvio padrão $(0,75 \%)^{9}$ no endividamento com a variação de 1 desvio padrão do risco (11\%). Já o segundo coeficiente, de -0.279 , representa a importância de 0,180 desvios padrões $(3,1 \%)$ do endividamento, para o mesmo nível de choque no risco, que seria 4,1 vezes maior do que a regressão estimada sem o instrumento. Um nível semelhante de disparidade no endividamento ( $3,1 \%$ do ativo) é esperado segundo o modelo, por exemplo, entre uma firma com $\mathrm{R} \$ 1$ bi de vendas líquidas anuais

\footnotetext{
${ }^{8}$ A regressão em primeiro estágio referente a regressão com variável instrumental (VI), na parte inferior da tabela 4, apresenta estatística $F$ de 22.72, com p-valor de 2.2e-16 e $\mathrm{R}^{2}$ de 72,5\%, mostrando que não haveria problema de fraqueza do instrumento utilizado.

${ }^{9} \mathrm{O}$ desvio padrão da alavancagem da amostra é de $17 \%$ do ativo, ou em média R\$ 255 milhões, dada a mediana do ativo total da base de $\mathrm{R} \$ 2.324,30$ milhões por empresa.
} 
com relação a uma firma com $\mathrm{R} \$ 30$ bilhões, o que retrata o potencial impacto do risco idiossincrático.

Observando as regressões por MQO combinando os fatores da volatilidade idiossincrática e volatilidade EBIT, enquanto a primeira é apenas significativa a $5 \%$, a segunda se mostra significativa com coeficiente de -0.300 a nível de $1 \%$. Quando estimados conjuntamente o coeficiente da volatilidade EBIT reduz para 0.187 e a significância cai para acima do nível de 10\%, com o coeficiente do risco idiossincrático praticamente inalterado.

Com os instrumentos para lidar com problema de causalidade reversa, a volatilidade idiossincrática passa a ser estatisticamente e economicamente significa (-0.321 a 1\%), enquanto a volatilidade do EBIT não é significativa (0.009). Uma interpretação para esta diferença seria que o risco idiossincrático do retorno da ação é mais relevante para o controlador do que o risco do EBIT como um todo, que é parcialmente absorvido pelos minoritários. Outra visão seria a de que a volatilidade do EBIT é pouco significativa por causa da sua estimação anualizada, frente a origem dos dados diários da volatilidade idiossincrática.

Vemos, portanto, que o coeficiente encontrado de -0.279 na regressão instrumentalizada é mais do que 4 vezes o coeficiente da regressão por MQO: o aumento do valor absoluto do coeficiente estimado por variáveis instrumentais sugere que a elevação do endividamento implicou em um aumento do risco idiossincrático, mascarando os incentivos do aumento do risco idiossincrático para a redução do endividamento. Controlar o efeito do risco idiossincrático pelo efeito de sua causalidade reversa com o endividamento nos revela um canal pelo qual a aversão ao risco dos gestores impacta significativamente a tomada de decisão.

A conclusão desta seção é a de que o fator idiossincrático de volatilidade tem potencial de apresentar efeitos significativos na estrutura de capital das firmas, tanto estatisticamente quanto economicamente, caso seja utilizado um instrumento apropriado. As hipóteses iniciais são validadas, e na seção seguinte são realizados testes de robustez dos resultados. 


\section{6. Análise de Robustez}

Nesta seção são analisados dois efeitos que podem dar maior confiança nos resultados: a sensibilidade do resultado ao uso de outras medidas de volatilidade idiossincrática e o efeito da participação do governo na sensibilidade ao risco.

\section{1}

\section{Outras medidas de risco idiossincrático}

Em seu artigo de 2001, Goyal e Santa Clara observam uma relação positiva entre a volatilidade média das firmas e os retornos de mercado através de diferentes medidas de volatilidade para as firmas, que incluem não somente o risco sistêmico, como também o risco idiossincrático. As três medidas utilizadas por Goyal e Santa Clara (2001) foram (1) a volatilidade média diária total das ações - disponível desde 1962; (2) a volatilidade mensal média total das ações - utilizada por apresentar característica semelhante a diária e estar disponível desde 1926; e (3) a volatilidade idiossincrática média dos ativos. A motivação para o uso da volatilidade (3) foi de verificar que a relação positiva com os retornos é explicada majoritariamente pela componente idiossincrática da volatilidade e não pelo risco sistêmico.

Para obter a volatilidade total, Goyal e Santa Clara (2001) calculam a média dos retornos quadrados dos ativos para cada mês da sua amostra. Ela é calculada de forma análoga às equações (4) e (5), substituindo os resíduos do retorno de mercado diretamente pelo retorno da ação $\mathrm{i}$, adicionando um produto dos retornos de controlar da autocorrelação $\left(s_{i}\right)$, conforme as equações (9) e (10). ${ }^{10}$ A medida se assemelha ao cálculo de uma volatilidade, pois a média de retornos diária dos ativos é próxima de zero.

\footnotetext{
${ }^{10}$ Goyal e Santa Clara (2001) adicionam a etapa de calcular a volatilidade média dos ativos para utilização deste fator para prever retornos dentro de uma carteira. Neste trabalho o procedimento de construção da variável instrumental substitui esta etapa, de forma que utilizamos o efeito médio de uma carteira da indústria para prever o impacto no endividamento.
} 
VolTotal $_{i t(m)}=\sqrt{\sum_{d=1}^{20}\left(r_{i d}^{2}+s_{i} * r_{i d} * r_{i(d-1)}\right)}$
VolTotal $_{i t}=\frac{1}{12} \sum_{m=1}^{12}$ VolTotal $_{i t(m)}$

A volatilidade total de baixa frequência, que utiliza dados mensais, é calculada com base no retorno quadrático médio das ações e regredido contra os retornos do mês subsequente. A volatilidade idiossincrática, por sua vez, é calculada pelos resíduos quadráticos médios das ações, que são calculados a partir de um modelo de mercado (CAPM) para os retornos diários de ações nos EUA, em uma amostra entre 21 e 20 observações diárias em cada mês.

Neste tópico procuramos analisar o modelo de endividamento utilizando medidas de risco análogas a de Goyal e Santa Clara (2001). São consideradas neste trabalho: (i) a volatilidade idiossincrática de baixa frequência, no mesmo período amostral de 2003 a 2017, para verificar se esta apresenta comportamento semelhante à volatilidade diária; (ii) a volatilidade total, para verificarmos se, confundindo o risco idiossincrático ao sistêmico, ainda conseguimos mensurar um efeito relevante; (iii) a volatilidade idiossincrática máxima do ano para verificar se os choques de volatilidade durante o ano norteiam a tomada de decisão dos gestores; e (iv) a volatilidade idiossincrática usando o modelo Fama e French (1993), para verificarmos se um modelo com mensuração mais precisa do risco idiossincrático retornaria um efeito mais significativo no modelo.

A volatilidade de baixa frequência (i) utiliza o módulo do resíduo do modelo CAPM para o período anterior (calculada mensalmente e tomamos a média dos 12 meses para o valor do ano), e é esperado uma performance inferior à da volatilidade que utiliza dados diários. A volatilidade total (ii) medida por Goyal e Santa Clara (2001), por incluir o risco idiossincrático, deve apresentar significância similar. A volatilidade máxima do período (iii) procura reforçar o sinal de picos de volatilidades na amostra, que podem estar diluídos pela frequência anual da agregação dos dados. Por fim, para a volatilidade medida pelo modelo Fama e French (iv) espera-se uma melhor performance pela adição do 
prêmio de risco SMB (também utilizado da base NEFIN-USP) no modelo de precificação - o prêmio HML não se mostrou significativo para explicar os retornos e, portanto, não foi considerado.

Para efeito de comparabilidade, na figura 5 a volatilidade total do índice Ibovespa é comparada às volatilidades idiossincráticas no período, medidas em desvios padrões dos retornos de diários. Na figura 5 é possível observar as volatilidades idiossincráticas maiores do que o mercado e a volatilidade puramente idiossincrática apresentando o maior valor.

A tabela 5 mostra na primeira coluna uma baixa significância da volatilidade de baixa frequência, como esperado apesar do controle pelo instrumento da volatilidade da indústria, com coeficiente de $-0,057$ e não significativo. $\mathrm{Na}$ regressão (ii) a volatilidade total apresenta coeficiente de $-0,380$ e significativo a $1 \%$, indicando um comportamento do controlador significativo, como esperado, porém não estatisticamente distinto da volatilidade idiossincrática. Na regressão (iii) a volatilidade máxima performa de forma similar à volatilidade média do período, com coeficiente significativo a $1 \%$ de $-0,221$. Finalmente, na regressão (iv) a volatilidade com critério Fama French também é significativa, com coeficiente negativo de -0.327 significativo a $1 \%$ - resultados dentro do esperado pela teoria, porém sem incremento significativo com relação a volatilidade idiossincrática da tabela 4 .

Em análises não reportadas são testados instrumentos alternativos como a volatilidade da indústria calculada como um ativo, a volatilidade idiossincrática defasada e dívida bruta defasada, além do cálculo da volatilidade com prêmio de risco do mercado americano. Não foram encontrados resultados significativamente melhores do que o uso da média da volatilidade da indústria. 


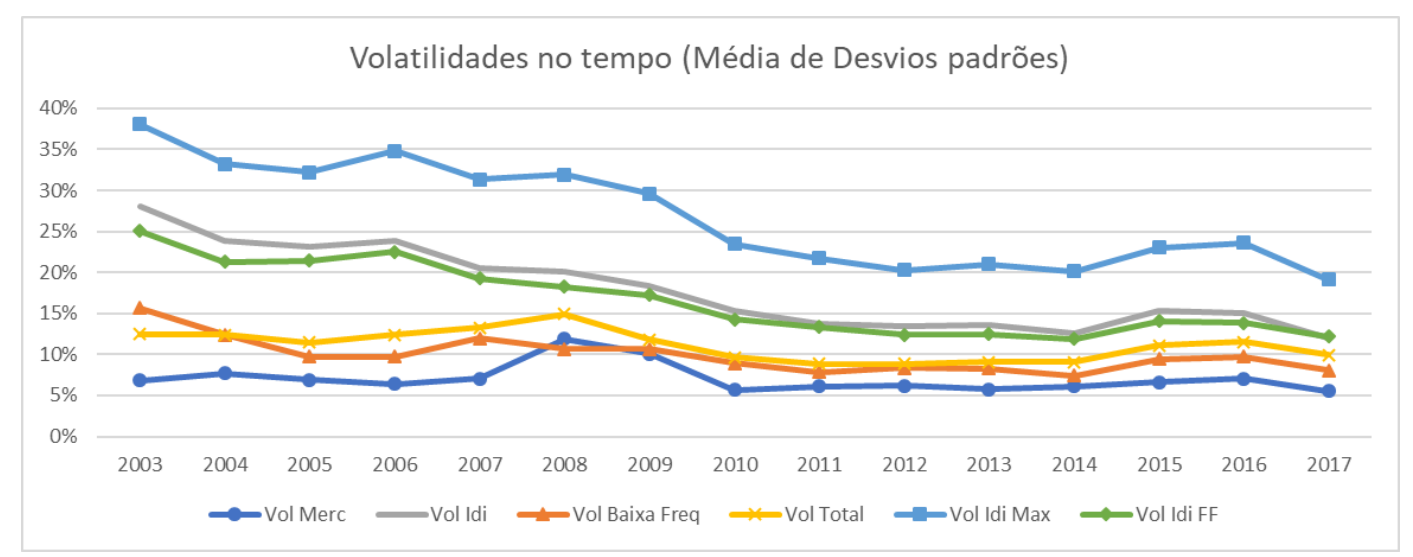

Figura 5 - Volatilidades no tempo

\section{2}

\section{Efeito da participação do governo}

O governo como controlador de firmas de capital aberto é um tema relevante no contexto da literatura de finanças corporativas. La Porta e Shleifer (1999) estudam os grupos controladores das firmas ao redor do mundo e encontram uma participação de $20 \%$ do governo dentre as maiores firmas de capital aberto ausente apenas em 6 de 27 países estudados.

Na literatura internacional, Dewenter e Malatesta (2001) identificam que firmas com participação do governo apresentam maior alavancagem do que firmas privadas, além de menor rentabilidade e uso mais intensivo de mão-de-obra. Segundo os autores, o embasamento teórico para este maior nível de endividamento seriam as garantias implícitas oferecidas pelo governo como acionista controlador. O governo seria também um agente com menor aversão a risco do que o agente privado, e a teoria prevê que a aversão ao risco do gestor/acionista deveria afetar as preferências de endividamento das firmas.

Para testar a sensibilidade das firmas ao risco idiossincrático, e a hipótese de que as firmas do governo seriam menos sensíveis, a equação (1) é estendida de acordo com a equação (11). Adicionamos uma dummy de participação governo e uma interação deste fator com a volatilidade idiossincrática. 


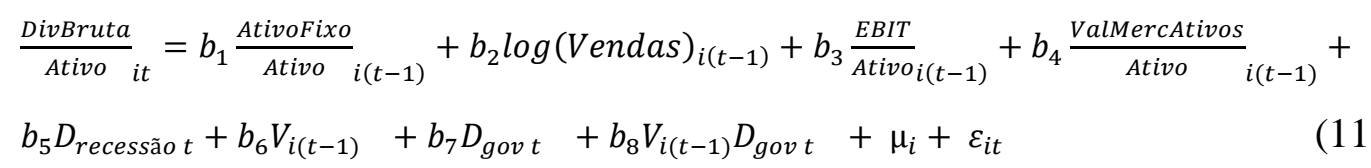

A dummy de participação do governo é definida como 1 caso o governo apresente participação direta ou indireta de pelo menos $10 \%$ da firma no ano t, seguindo o critério final-link-10 de La Porta e Shleifer (1999) e a classificação de firmas segue a realizada por Fernandes (2019). ${ }^{11}$ As 23 empresas “majoritárias" e 13 empresas com participação não majoritária do governo estão listadas na tabela 6 .

O coeficiente de interesse na equação (8) é $b_{8}$, que mede a significância da interação da volatilidade e a dummy de governo, e a hipótese II (menor sensibilidade da alavancagem das firmas do governo ao risco) é definida como:

$$
\begin{aligned}
& H_{0}^{2}: b_{6}+b_{8}=0 \\
& H_{1}^{2}: b_{6}+b_{8} \neq 0
\end{aligned}
$$

O teste conjunto de significância considera os parâmetros $b_{6}$ e $b_{8}$, respectivamente coeficientes do risco idiossincrático e interação da dummy de governo e risco. $\mathrm{O}$ sinal esperado para o coeficiente $b_{8}$, dado Dewenter e Malatesta (2001), é o oposto do sinal do coeficiente $b_{6}$, ou seja, positivo, de forma que a soma destes seja estatisticamente equivalente a zero, significando uma indiferença das firmas do governo com relação ao risco idiossincrático. A validação desta segunda hipótese reforçaria a teoria que o sinal negativo da relação entre risco e endividamento seria baseado na aversão a risco do gestor, e que firmas do governo seriam menos sensíveis ao risco que firmas privadas em geral.

Primeiro analisamos a alavancagem média da amostra estratificando as firmas do governo e demais firmas a fim de verificar se os dados apresentam a mesma característica de Dewenter e Malatesta (2001) de maior alavancagem do governo.

\footnotetext{
11 A base de dados de participação acionária, gentilmente cedida por Fernandes (2019), foi verificada através da base Economática, onde a participação histórica dos principais acionistas para as 329 empresas da base foi coletada de 2003 a 2017. Foram identificados 6.654 grandes acionistas distintos destas empresas, e 132 classificados como acionistas controlados pelo governo ou órgãos do governo.
} 
Na tabela 7 identificamos que, segundo a alavancagem contábil, as firmas com participação majoritária do governo são menos alavancadas e as não-majoritárias mais alavancadas. Já segundo a alavancagem por valor de mercado, ambos os grupos de firmas do governo possuem maior endividamento, sendo o majoritário com coeficiente mais significativo (estatística t de 3,41).

Observa-se pelas estatísticas descritivas comparativas da tabela 7 e pela figura 6 que a dívida bruta das empresas do governo majoritárias esteve abaixo da média das firmas privadas. A dívida bruta sobre ativos total variou do mínimo de 25,7\% em 2004 a 32,1\% em 2015, com as variações para firmas majoritárias e com participação do governo sendo $25,1 \%$ a $28,1 \%$ e $32,8 \%$ a $36,7 \%$ nos mesmos períodos respectivamente. Notadamente as firmas do governo majoritárias apresentam alavancagem menor, com estatística t de 5,31 para o período total da amostra, e as firmas com participação apresentam alavancagem superior a média com estatística t de $-3,96$.

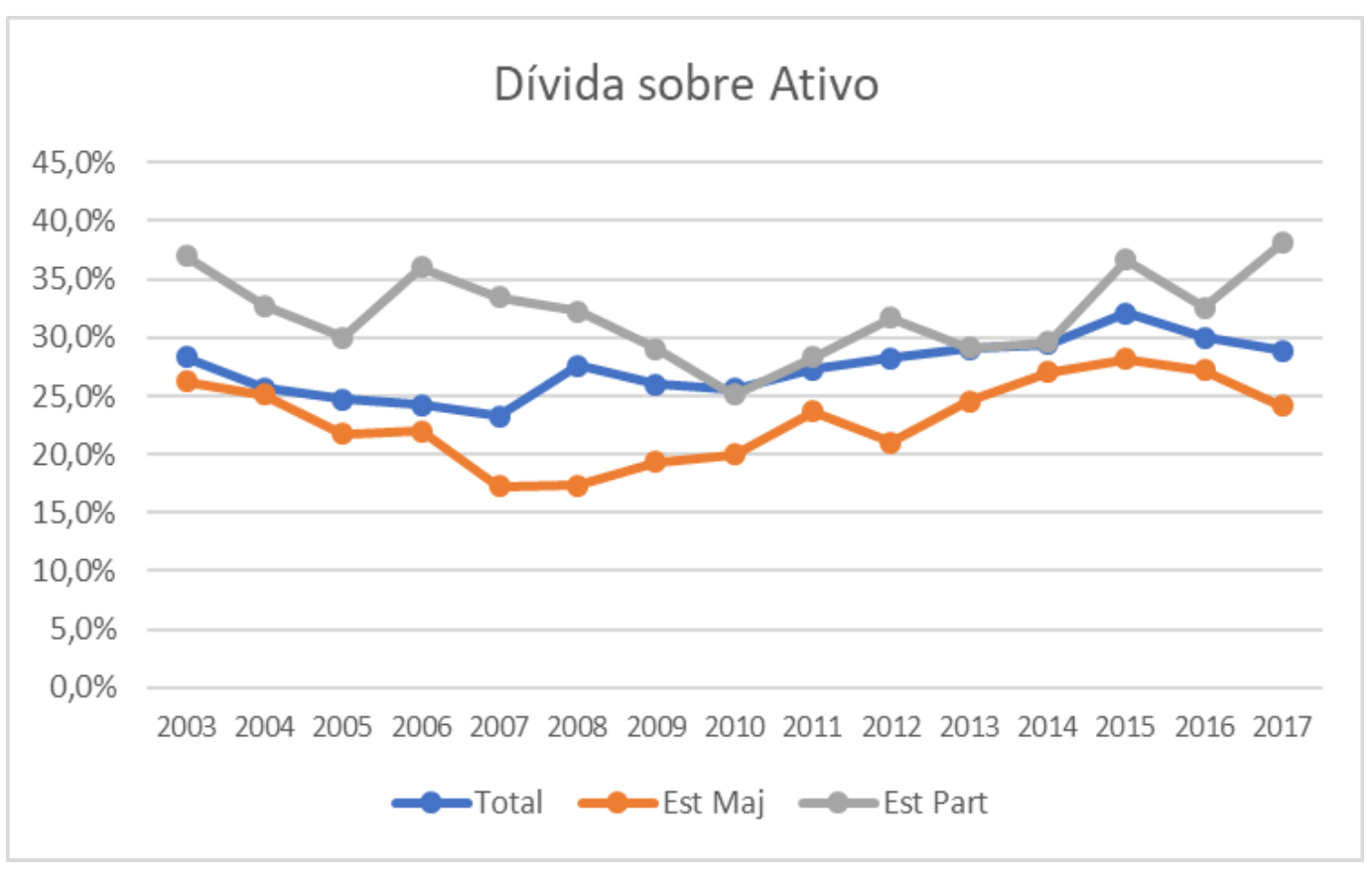

Figura 6 - Dívida sobre ativo total e das firmas do governo

Já com relação ao critério de interesse, a volatilidade idiossincrática, as firmas privadas e do governo convergem, salvo para o início da amostra, e diminuem de magnitude no período de menor crescimento, conforme apresenta a figura 7 . 




Figura 7 - Evolução da volatilidade idiossincrática

Da figura 8 é possível observar que o governo participa de $13 \%$ das firmas, com relação a quantidade de firmas. Já pela figura 9 verifica-se que o governo apresenta participação mais significativa em termos de valor de mercado na Bolsa: 28,3\% em Dez/2017, por exemplo.

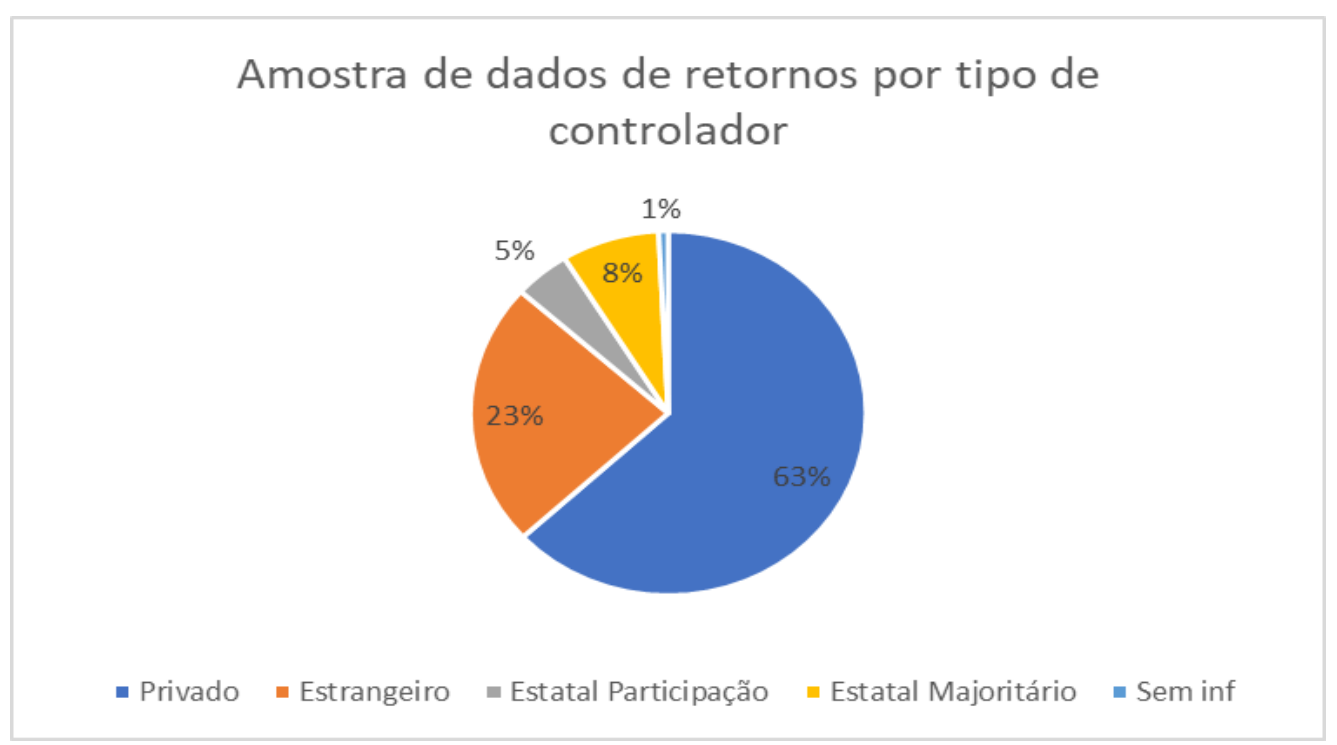

Figura 8 - Participação de firmas do governo 


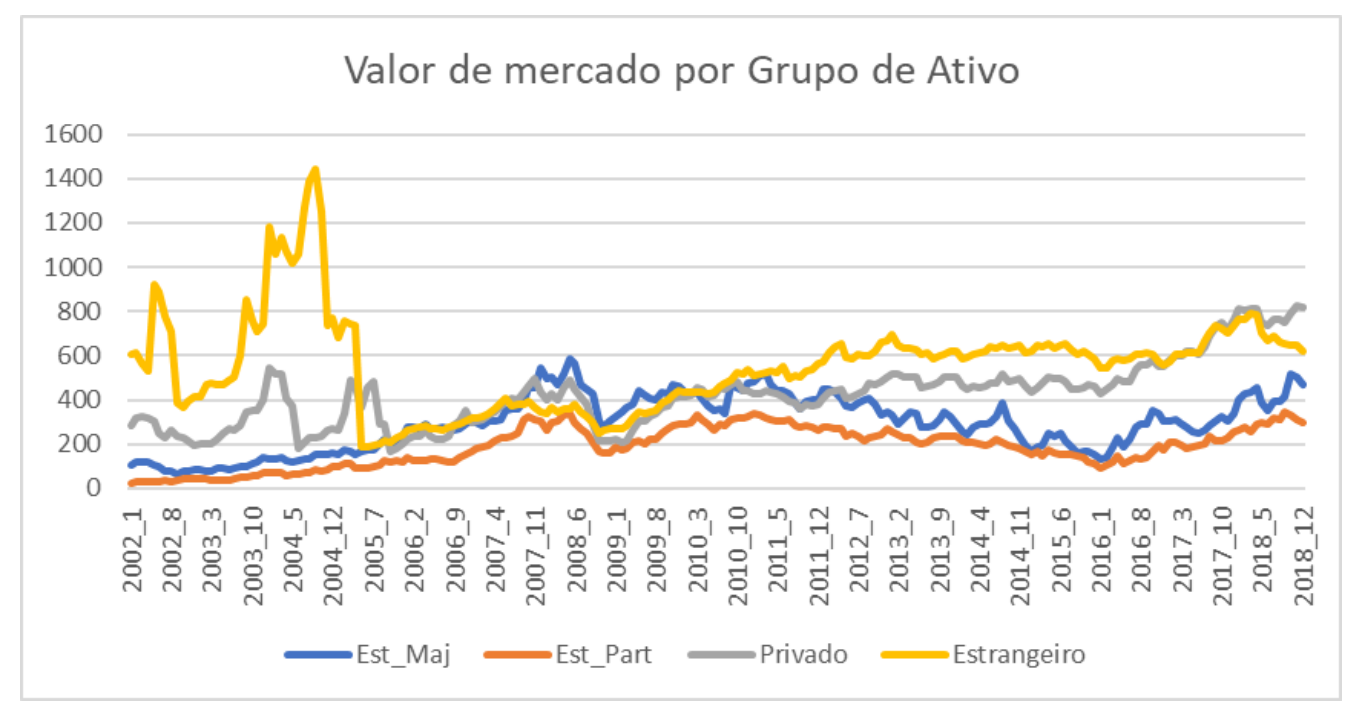

Figura 9 - Evolução do valor de mercado de firmas do governo

Como forma de aumentar a confiança dos resultados, estimamos a regressão com instrumento introduzindo a interação do risco idiossincrático com a dummy de empresa controlada pelo governo ou que tenham o governo como um dos controladores. Em tese, o governo deve ser menos sensível ao risco idiossincrático que investidores privados. Sendo assim, espera-se que o coeficiente da interação da dummy de governo com o risco idiossincrático seja positivo.

Na tabela 8 averiguamos que o instrumento utilizado na regressão de $1^{\circ}$ estágio se mantém significativo com a adição da dummy de governo, com estatística-F de 21,881. O coeficiente encontrado para a interação do risco com a dummy foi positivo $(0,301)$ e o teste de hipótese é rejeitado $\left(H_{0}^{2}: b_{6}+b_{8}=0\right)$, sugerindo portanto que o efeito total do risco idiossincrático para firmas do governo seria insignificante. O coeficiente do risco é de -0.301 com p-valor de inferior a $1 \%$, a interação com o governo apresentou coeficiente de 0.301 (p-valor de 0.156), e o resultado para a soma dos coeficientes é zero (p-valor de 0.999), ou seja, indistinguível de zero e sem relevância econômica. A análise de firmas do governo mostra, portanto, consistência com o fato do agente público ser menos sensível ao risco. 


\section{7. \\ Conclusões}

Existe uma controvérsia em apreçamento de ativos sobre se o risco idiossincrático é relevante ou não para as empresas. Goyal e Santa Clara (2001) encontram uma relação e a interpretam como fricções de mercado, enquanto outros autores como Angelidis et al. (2006) questionam a seleção dos períodos de amostragem e associam o efeito observado a empresas pequenas e com falta de liquidez.

Independentemente de o risco idiossincrático afetar ou não os retornos esperados de equilíbrio dos ativos, é muito plausível que este tenha um efeito considerável sobre decisões de tomada de risco na empresa dado a dificuldade crescente de eliminá-lo, como visto por Campbell (2001), sobretudo nos casos de uma estrutura acionária concentrada, onde a diversificação é mais difícil. Este ponto seria, portanto, menos controverso do que a afirmação de Goyal e Santa Clara (2001) e, ainda assim, não houve nenhum estudo que tentou associar o risco idiossincrático a estas decisões - sendo esta a principal contribuição deste trabalho.

Coletamos uma amostra de empresas brasileiras, tradicionalmente com controle acionário concentrado, e construímos uma medida de risco idiossincrático, observando que de fato existe um efeito significativo. As regressões com variáveis instrumentais mostram que 1 desvio padrão de variação do risco idiossincrático impacta em uma redução de endividamento de 0,18 desvio padrão. Ainda, se analisarmos as empresas do governo, o mesmo efeito não é observado, o que é condizente com agentes menos preocupados com risco e maximização de lucro. Risco idiossincrático é, portanto, relevante para a tomada de decisão de endividamento, independentemente do risco total - risco este que é parcialmente compartilhado com os acionistas minoritários, enquanto o risco idiossincrático se concentra com o controlador e por isso espera-se uma aversão maior.

Certamente alguns pontos podem ser mais aprofundados, como medidas alternativas de risco total, utilização de dados com maior frequência que a anual e a introdução de medidas de concentração acionária. Dito isto, uma vez que por construção o risco idiossincrático utilizado é progressivamente eliminado através 
da diversificação de ativos e não é uma boa proxy do risco total, acreditamos que os resultados serão robustos a outras medidas de risco a serem criadas futuramente. 


\section{Referências Bibliográficas}

ANGELIDIS; TIMOTHEOS; TESSAROMATIS. Idiosyncratic Risk and Expected Returns: A Regime Switching Approach. Disponível em SSRN 1006624, 2006.

BALI, T. G. et al. Does idiosyncratic risk really matter? The Journal of Finance, 60(2), p. 905-929, 2005.

BÉGIN, J.F.; DORION, C.; GENEVIÈVE G.. Idiosyncratic jump risk matters: Evidence from equity returns and options. The Review of Financial Studies 33.1 p. 155-211, 2020.

CAMPBELL, J. Y.; et al. Have individual stocks become more volatile? An empirical exploration of idiosyncratic risk. The Journal of Finance 56.1, p. 1-43, 2001.

DEWENTER, K. L.; MALATESTA, P. H. State-owned and privately owned firms: An empirical analysis of profitability, leverage, and labor intensity. American Economic Review 91.1, p. 320-334, 2001.

FAMA, E. F.; AND KENNETH R. F. The cross-section of expected stock returns. The Journal of Finance 47.2, p. 427-465, 1992.

FERNANDES, D. Empresas do Governo e Multinacionais: 0 que elas têm em comum nas decisões de Estrutura de Capital e Payout? Diss. PUC-Rio, 2019.

FRANK, M.Z.; GOYAL, V.K. Capital structure decisions: which factors are reliably important? Financial management, 38(1), p. 1-37, 2009

FU, F. Idiosyncratic risk and the cross-section of expected stock returns. Journal of financial Economics 91.1, p. 24-37, 2009.

GALDI, F. C.; SECURATO, J. R. O risco idiossincrático é relevante no mercado brasileiro? Revista Brasileira de Finanças 5.1, p. 41-58, 2007.

GOMES, G.L.; LEAL, R.P. Determinantes da estrutura de capitais das empresas brasileiras com ações negociadas em bolsas de valores. Finanças Corporativas. São Paulo: Atlas, 2001.

GOYAL, A.; SANTA-CLARA, P. Idiosyncratic risk matters! The Journal of Finance 58.3, p. 975-1007, 2003.

GRAHAM, J.R.; LEARY, M.T.; ROBERTS, M.R. A century of capital structure: The leveraging of corporate America. Journal of Financial Economics, 118(3), p. 658-683, 2015. 
KAYO, E.K.; KIMURA, H. Hierarchical determinants of capital structure. Journal of Banking \& Finance, 35(2), p.358-371, 2011.

LA PORTA, R.; LOPEZ-DE-SILANES, F.; SHLEIFER, A. Corporate ownership around the world. The Journal of Finance 54.2, p. 471-517, 1999.

LEAL, R. P. C.; DA SILVA, A. L. C.; VALADARES, S. M. Estrutura de controle das companhias brasileiras de capital aberto. Revista de Administração Contemporânea 6, no. 1, p. 7-18, 2002.

LEMMON, M.L.; ROBERTS, M.R; ZENDER, J.F. Back to the beginning: persistence and the cross-section of corporate capital structure. The Journal of Finance, 63(4), p.1575-1608, 2008.

MALKIEL, B. G.; XU, Y. Idiosyncratic risk and security returns. University of Texas at Dallas, 2002.

MINTON, B. A.; SCHRAND, C. The impact of cash flow volatility on discretionary investment and the costs of debt and equity financing. Journal of Financial Economics 54.3, p. 423-460, 1999.

MODIGLIANI, F.; MILLER, M.H. The cost of capital, corporation finance and the theory of investment. The American, 1, p. 3, 1958.

MOTA, A.F.; COELHO, A.C.D.; HOLANDA, A.P. Opção por endividamento na estrutura de capital: evidências em firmas brasileiras. Contextus-Revista Contemporânea de Economia e Gestão, 12(1), 2014.

MYERS, S. C.; MAJLUF, N. S. Corporate financing and investment decisions when firms have information that investors do not have. No. w1396. National Bureau of Economic Research, 1984.

NETO, F.A.S.; DA SILVA, J.R.R.; GIRÃO, L.F.A.P. Determinantes Da Volatilidade Idiossincrática no Mercado Acionário Brasileiro. XVIII USP International Conference in Accounting. 2018.

RAJAN, R.G.; ZINGALES, L. What do we know about capital structure? Some evidence from international data. The Journal of Finance, 50(5), p.1421-1460, 1995. 


\section{Apêndice A - Descrição das Variáveis}

Descrição dos tickers da Bloomberg utilizados na composição das variáveis utilizadas nas regressões de estrutura de capital.

- Setor da Indústria: A classificação utilizada foi a do ticker “INDUSTRY_SECTOR” informado pela Bloomberg;

- Dívida Bruta sobre Ativo: Divisão da Dívida Bruta (SHORT_AND_LONG_TERM_DEBT) pelo total dos ativos (BS_TOT_ASSET);

- Dívida Bruta sobre Capital: Divisão da Dívida Bruta (SHORT_AND_LONG_TERM_DEBT) pelo Capital. O Capital é o valor total dos ativos (BS_TOT_ASSET) menos o valor de balanço das ações (TOTAL_EQUITY) mais o valor de mercado destas (CUR_MKT_CAP);

- Ativo Total: Ticker BS_TOT_ASSET;

- Valor de Mercado dos Ativos: Mesma fórmula do Capital, valor total dos ativos (BS_TOT_ASSET) menos o valor de balanço das ações (TOTAL_EQUITY) mais o valor de mercado destas (CUR_MKT_CAP);

- Tamanho - Log da Venda líquida: Logaritmo natural (base e) da venda líquida da firma (SALES_REV_TURN) em milhões de reais;

- Tangibilidade: Ativos tangíveis (TANGIBLE_ASSETS) sobre total dos ativos (BS_TOT_ASSET);

- Lucratividade: EBIT sobre Ativos (BS_TOT_ASSET);

- Oportunidade de crescimento - Market to book value: Valor de Mercado dos Ativos (descrito anteriormente) sobre valor contábil dos ativos (BS_TOT_ASSET);

- Participação acionária do governo: Ticker para participação acionária do governo presente na Bloomberg, porém não alimentado para firmas brasileiras. Dados dos principais acionistas das firmas brasileiras coletados na Economática, para cada ticker de ativo da base, considerando todos os tipos de ação (código TodTipos). Posteriormente a classificação de agentes relacionados ao governo foi realizada pelo autor e as participações totais ano a ano por firma agregadas na base de dados. Base de dados conciliada com a de Fernandes (2019). 


\section{Apêndice B - Tabelas}

Tabela 1 - Dados de balanço de variáveis para análise da estrutura de capital

A amostra de dados anuais cobre o período de 2003 a 2017, inclui apenas firmas não financeiras listadas na B3 (antiga BM\&F). Os dados foram agrupados em três blocos: A - Total das firmas; B - Firmas na $1^{\text {a }}$ parte da amostra; e C - Firmas na $2^{\mathrm{a}}$ parte da amostra.

A - Total das fimas

\begin{tabular}{|c|c|c|c|c|c|c|c|c|}
\hline Variáveis & Contagem & Média & Desv. pad & Min & $\operatorname{Petl}(25)$ & Medizna & $\operatorname{Petl}(75)$ & $\mathrm{Mg}$ \\
\hline Divida/Ativo & 2873 & 0,27 & 0,17 & 0 & 0,14 & 0,28 & 0,4 & 0,59 \\
\hline $\begin{array}{l}\text { Divida / Valor } \\
\text { de Mercado }\end{array}$ & 2830 & 0,34 & 0,25 & 0 & 0,13 & 0,31 & 0,52 & 0,83 \\
\hline Lucratividade & 2873 & 0,07 & 0,07 & $-0,06$ & 0,02 & 0,06 & 0,11 & 0,21 \\
\hline Q-Tobin & 2830 & 1,39 & 0,69 & 0,64 & 0,92 & 1,15 & 1,65 & 3,31 \\
\hline Log(Verdas) & 2873 & 13,76 & 2,85 & 0 & 12,98 & 14,17 & 15,23 & 19,64 \\
\hline Tangibilidade & 2223 & 0,32 & 0,23 & 0,004 & 0,11 & 0,29 & 0,49 & 0,8 \\
\hline
\end{tabular}

B - Peńodo de crescimento de 2003 a 2008

\begin{tabular}{lcccccccc}
\hline Divida/Ativo & 985 & 0.25 & 0.16 & 0.00 & 0.14 & 0.25 & 0.37 & 0.59 \\
Divida/ Valor & 967 & 0.31 & 0.23 & 0.00 & 0.12 & 0.27 & 0.45 & 0.83 \\
de Mercado & 985 & 0.08 & 0.07 & -0.06 & 0.02 & 0.08 & 0.13 & 0.21 \\
Lucratividade & 967 & 1.42 & 0.70 & 0.64 & 0.92 & 1.21 & 1.31 & 3.31 \\
Q-Tobin & 985 & 13.62 & 2.60 & 0.00 & 12.87 & 13.97 & 14.95 & 19.19 \\
Log(Verdias) & 661 & 0.38 & 0.22 & 0.004 & 0.20 & 0.37 & 0.53 & 0.80 \\
Tampibilidade & 661 &
\end{tabular}

C-Periodo de menor crescineerto de 2009 a 2017

\begin{tabular}{lcccccccc}
\hline Divida/Ativo & 1,888 & 0.28 & 0.17 & 0.00 & 0.14 & 0.30 & 0.41 & 0.59 \\
Divida/ Valor & 1,863 & 0.35 & 0.25 & 0.00 & 0.14 & 0.33 & 0.54 & 0.83 \\
de Mercado & 1,888 & 0.06 & 0.07 & -0.06 & 0.02 & 0.06 & 0.10 & 0.21 \\
Lucratividade & 1,863 & 1.37 & 0.69 & 0.64 & 0.92 & 1.13 & 1.60 & 3.31 \\
Q-Tobin & 1,888 & 13.84 & 2.97 & 0.00 & 13.09 & 14.28 & 15.38 & 19.64 \\
Log(Verdas) & 1,562 & 0.29 & 0.23 & 0.004 & 0.08 & 0.25 & 0.45 & 0.80 \\
Tampibilidade & 1,82 &
\end{tabular}


Tabela 2 - Amostra de empresas por setor

A amostra de dados anuais cobre o período de 2003 a 2017, inclui apenas firmas não financeiras listadas na B3 (antiga BM\&F), totalizando 329 firmas. A classificação setorial das firmas em 9 tipos segue o ticker "INDUSTRY_SECTOR" do Bloomberg.

\begin{tabular}{|c|c|c|c|c|c|c|c|c|c|c|}
\hline & Total & Comunicapies & $\begin{array}{c}\text { Consumo } \\
\text { não ciclico }\end{array}$ & $\begin{array}{l}\text { Infia } \\
\text { estrutura }\end{array}$ & Inchastrial & $\begin{array}{c}\text { Consumo } \\
\text { ciclico }\end{array}$ & $\begin{array}{c}\text { Materiais } \\
\text { báaicos }\end{array}$ & Energia & Tecnologia & Outros \\
\hline 2003 & 122 & 18 & 11 & 24 & 14 & 24 & 24 & 3 & 1 & 3 \\
\hline 2004 & 123 & 16 & 13 & 25 & 13 & 25 & 23 & 5 & 1 & 2 \\
\hline 2005 & 152 & 16 & 19 & 29 & 19 & 29 & 29 & 7 & 2 & 2 \\
\hline 2006 & 175 & 13 & 26 & 35 & 20 & 36 & 29 & 8 & 5 & 3 \\
\hline 2007 & 206 & 14 & 41 & 36 & 25 & 44 & 28 & 8 & 6 & 4 \\
\hline 2008 & 207 & 13 & 44 & 36 & 26 & 46 & 28 & 5 & 5 & 4 \\
\hline 2009 & 207 & 12 & 43 & 37 & 26 & 48 & 26 & 5 & 6 & 4 \\
\hline 2010 & 221 & 12 & 45 & 37 & 31 & 50 & 29 & 7 & 6 & 4 \\
\hline 2011 & 226 & 12 & 50 & 37 & 30 & 54 & 25 & 8 & 6 & 4 \\
\hline 2012 & 223 & 10 & 49 & 37 & 29 & 55 & 26 & 8 & 5 & 4 \\
\hline 2013 & 218 & 10 & 50 & 34 & 28 & 52 & 25 & 8 & 7 & 4 \\
\hline 2014 & 213 & 9 & 48 & 37 & 28 & 50 & 21 & 9 & 7 & 4 \\
\hline 2015 & 194 & 7 & 47 & 36 & 23 & 45 & 17 & 9 & 6 & 4 \\
\hline 2016 & 190 & 7 & 43 & 36 & 24 & 46 & 17 & 8 & 6 & 3 \\
\hline 2017 & 196 & 8 & 46 & 35 & 21 & 49 & 19 & 11 & 5 & 2 \\
\hline Total & 2873 & 137 & 575 & 511 & 357 & 653 & 366 & 109 & 74 & 51 \\
\hline
\end{tabular}




\section{Tabela 3 - Dados de volatilidades idiossincráticas e sistêmicas}

A amostra de dados resumidos anualmente de 2003 a 2017, incluindo apenas firmas não financeiras listadas na B3. Na tabela são apresentadas as volatilidades de mercado (VOL MKT), idiossincrática (VOL IDI), da indústria (VOL IDI IND) e a volatilidade EBIT (VOL EBIT), principais variáveis utilizadas na seção de resultados (5).

\begin{tabular}{lcccccccc}
\hline Variáveis & Cont & Média & $\begin{array}{c}\text { Desv. Pad } \\
\text { A-Total das firmas }\end{array}$ & $\begin{array}{c}\text { Min } \\
\text { Actl(25) }\end{array}$ & Mediana & Pctl(75) & Máx \\
\hline VOL MKT & 2873 & 0.07 & 0.02 & 0.06 & 0.06 & 0.06 & 0.07 & 0.12 \\
VOL IDI & 1846 & 0.17 & 0.11 & 0.00 & 0.09 & 0.12 & 0.21 & 0.94 \\
VOL IDI IND & 2871 & 0.17 & 0.06 & 0.09 & 0.13 & 0.15 & 0.20 & 0.36 \\
VOL EBIT & 2544 & 0.04 & 0.02 & 0.00 & 0.02 & 0.04 & 0.05 & 0.11 \\
\hline
\end{tabular}

\begin{tabular}{lcccccccc}
\multicolumn{10}{c}{ B-Periodo de crescimento de 2003 a 2008 } \\
\hline VOL MIKT & 778 & 0.07 & 0.004 & 0.06 & 0.07 & 0.07 & 0.07 & 0.08 \\
VOL IDI & 405 & 0.23 & 0.14 & 0.05 & 0.11 & 0.21 & 0.34 & 0.52 \\
VOL IDI IND & 776 & 0.23 & 0.06 & 0.10 & 0.21 & 0.23 & 0.27 & 0.36 \\
VOL EBIT & 538 & 0.03 & 0.02 & 0.00 & 0.01 & 0.03 & 0.04 & 0.11 \\
\hline
\end{tabular}

C-Periodo de menor crescimento de 2009 a 2017

\begin{tabular}{|c|c|c|c|c|c|c|c|c|}
\hline VOL MIKT & 2095 & 0.07 & 0.02 & 0.06 & 0.06 & 0.06 & 0.07 & 0.12 \\
\hline VOL IDI & 1846 & 0.17 & 0.11 & 0.00 & 0.09 & 0.12 & 0.21 & 0.94 \\
\hline VOL IDI IND & 2871 & 0.17 & 0.06 & 0.09 & 0.13 & 0.15 & 0.20 & 0.36 \\
\hline VOL EBIT & 2006 & 0.04 & 0.02 & 0.00 & 0.02 & 0.04 & 0.05 & 0.11 \\
\hline
\end{tabular}




\section{Tabela 4: Regressões da estrutura de capital}

O painel desbalanceado considera a amostra final de empresas da B3 de 2003 a 2017 com 2.873 empresas-ano e 329 firmas, mas que é reduzida devido a defasagem da dívida bruta com relação as variáveis independentes e pelo filtro das firmas com volatilidade idiossincrática calculada, resultando em 1.485 empresas-ano disponíveis. Três regressões em MQO e três com variável instrumental, alternando a inclusão do termo da volatilidade Ebit, para comparação com o risco idiossincrático. Dummies de período, intercepto e efeitos fixos de empresa são calculados e omitidos da tabela. Abaixo das colunas (4), (5) e (6) estão as respectivas regressões de $1^{\circ}$ estágio do instrumento utilizados - as volatilidades idiossincráticas das indústrias. Significâncias ${ }^{*} \mathrm{p}<0.1 ;{ }^{* *} \mathrm{p}<0.05 ;{ }^{* * *} \mathrm{p}<0.01$.

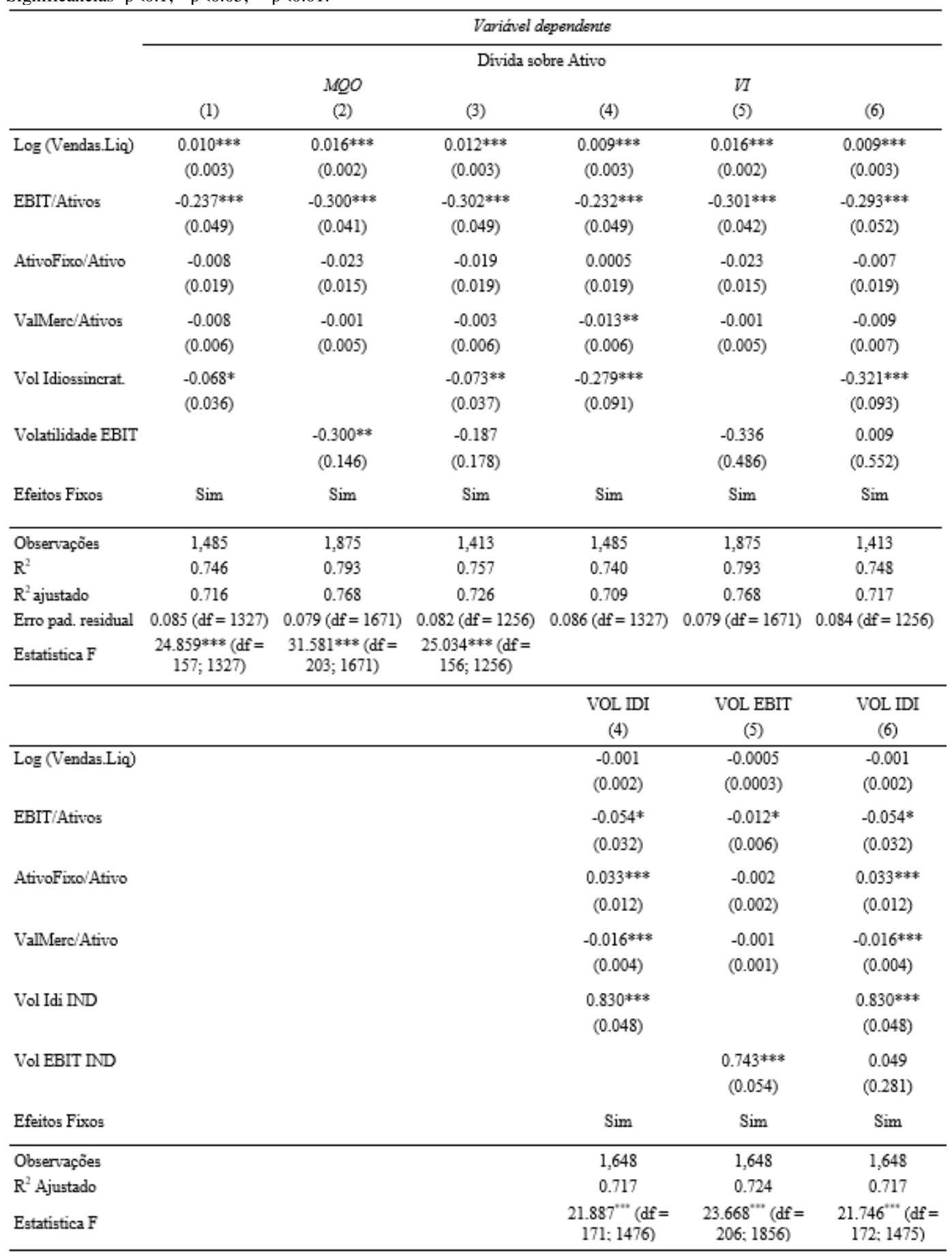


Tabela 5: Regressão da estrutura de capital variando o critério de volatilidade idiossincrática

Amostra de empresas não financeiras da B3 de 2003 a 2017. Regressões de dois estágios utilizando a (1) volatilidade de baixa frequência, (2), volatilidade total, (3) volatilidade idiossincrática máxima, (4) volatilidade idiossincrática pelo modelo Fama French, cada um utilizando a volatilidade média da indústria com seu respectivo critério de volatilidade. As variáveis independentes estão defasadas de um período com relação ao endividamento. Dummies de período, intercepto e efeitos fixos de firma omitidos da tabela.

\begin{tabular}{|c|c|c|c|c|}
\hline & \multicolumn{4}{|c|}{ Vaviável dependente } \\
\hline & \multicolumn{4}{|c|}{ Divida.Bruta sobre.Ativo } \\
\hline & (1) & (2) & (3) & (4) \\
\hline Log (Vendas.Liq) & $\begin{array}{c}0.011^{* * *} \\
(0.003)\end{array}$ & $\begin{array}{c}0.008^{* * *} \\
(0.003)\end{array}$ & $\begin{array}{c}0.009 * * * \\
(0.003)\end{array}$ & $\begin{array}{c}0.009 * * 8 \\
(0.003)\end{array}$ \\
\hline EBIT/Ativos & $\begin{array}{c}-0.239 * * 8 \\
(0.047)\end{array}$ & $\begin{array}{c}-0.224 * * 8 \\
(0.047)\end{array}$ & $\begin{array}{c}-0.235^{* * *} \\
(0.050)\end{array}$ & $\begin{array}{c}-0.228 * * * \\
(0.049)\end{array}$ \\
\hline AtivoFixo/AtivoTotal & $\begin{array}{l}-0.003 \\
(0.017)\end{array}$ & $\begin{array}{c}0.010 \\
(0.018)\end{array}$ & $\begin{array}{l}0.00001 \\
(0.019)\end{array}$ & $\begin{array}{c}0.003 \\
(0.019)\end{array}$ \\
\hline ValMerc/ValAtivos & $\begin{array}{l}-0.005 \\
(0.005)\end{array}$ & $\begin{array}{c}-0.011^{* *} \\
(0.005)\end{array}$ & $\begin{array}{c}-0.013^{* *} \\
(0.006)\end{array}$ & $\begin{array}{c}-0.013^{* *} \\
(0.006)\end{array}$ \\
\hline Vol Baixa Freq & $\begin{array}{l}-0.065 \\
(0.134)\end{array}$ & & & \\
\hline Vol Total & & $\begin{array}{c}-0.380^{* * *} \\
(0.105)\end{array}$ & & \\
\hline Vol Idi Máxima & & & $\begin{array}{c}-0.221^{* * 8} \\
(0.061)\end{array}$ & \\
\hline Vol Fama French & & & & $\begin{array}{c}-0.337 * * * \\
(0.098)\end{array}$ \\
\hline Efeitos Fixos & $\operatorname{Sim}$ & Sim & Sim & Sim \\
\hline Observações & 1,719 & 1,626 & 1,485 & 1,485 \\
\hline $\mathrm{R}^{2}$ & 0.768 & 0.743 & 0.736 & 0.738 \\
\hline $\mathrm{R}^{2}$ ajustado & 0.739 & 0.714 & 0.705 & 0.707 \\
\hline Erro pad. residual & $0.083(\mathrm{df}=1524)$ & $0.085(\mathrm{df}=1459)$ & $0.087(\mathrm{df}=1327)$ & $0.086(\mathrm{df}=1327)$ \\
\hline
\end{tabular}




\section{Tabela 6 - Firmas classificadas como "Estatal Majoritário" ou "Estatal Participação"}

As firmas seguem a classificação de Fernandes (2019) de participação do governo em "Estatal Majoritário" no caso de agentes do governo diretamente ou indiretamente detendo mais do que 50\% dos diretos de voto da firma, e "Estatal Participação" caso os direitos de voto estivessem entre 50\% e 10\%. A metodologia para o cálculo da participação seguiu o critério final-link 10\% presente em La Porta (1999).

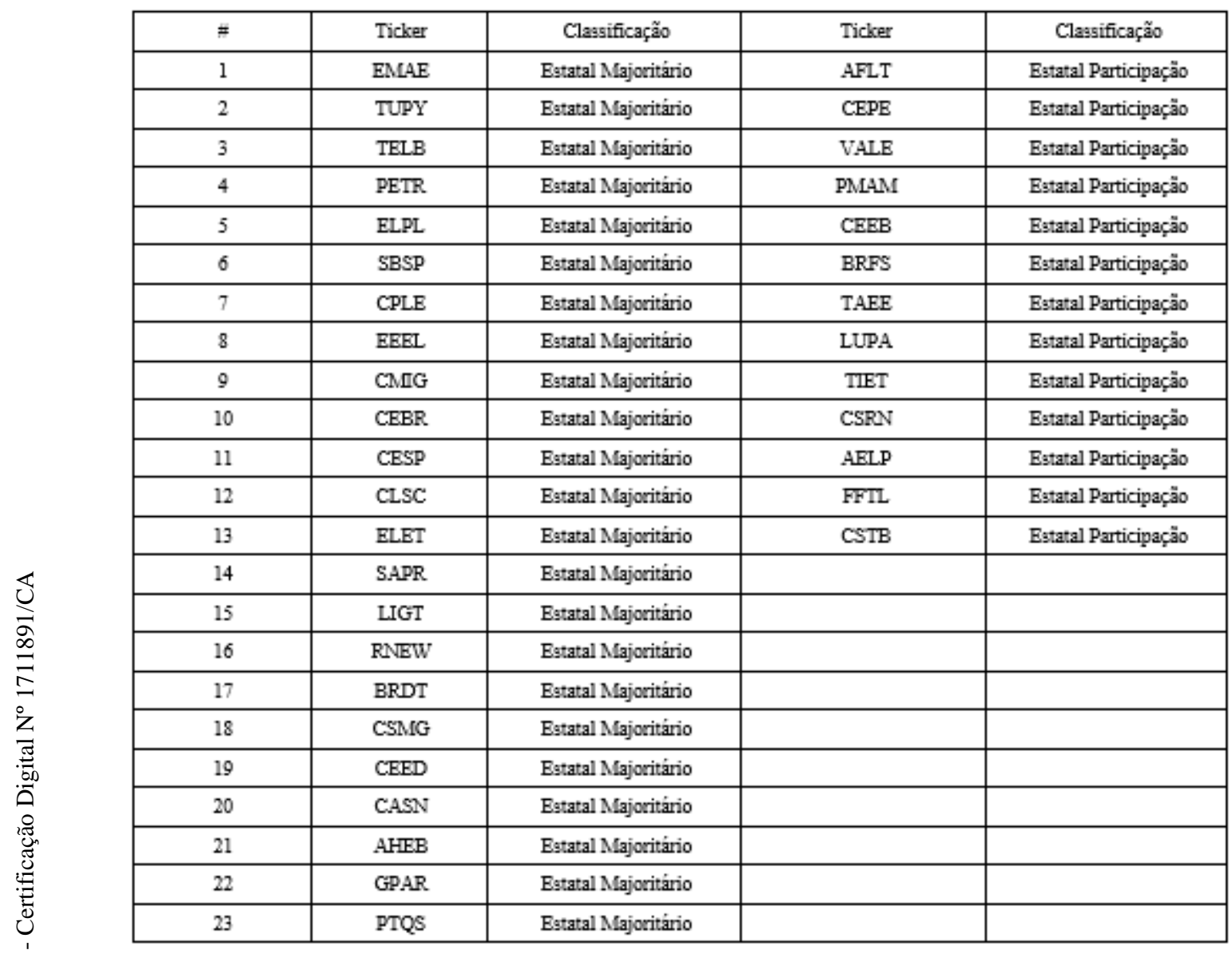




\section{Tabela 7 - Comparação da alavancagem por tipo de firma}

A amostra de dados anuais cobre o período de 2003 a 2017, inclui apenas firmas não financeiras listadas na B3 (antiga $\mathrm{BM} \& \mathrm{~F}$ ). Médias e desvios padrões das duas medidas de alavancagem são apresentados para cada tipo de firma da base de dados. Teste de hipótese relativo à comparação de médias de cada tipo de firma com o restante da base. Segundo a alavancagem contábil, as firmas com participação majoritária são menos alavancadas e as não-majoritárias mais alavancadas. Segundo a alavancagem por valor de mercado, ambos os grupos de firmas do governo possuem maior endividamento, sendo o majoritário com coeficiente mais significativo (estatística t de 3,41).

\begin{tabular}{lcccc}
\hline Variável & Estatal Maj & Estatal Part & Estrangeiro & Privado \\
\hline Média - Divida / Ativo & 0,23 & 0,32 & 0,24 & 0,29 \\
Média - Divida / Valor de Mercado & 0,38 & 0,36 & 0,25 & 0,36 \\
Dev Pad - Dívida / Ativo & 0,14 & 0,14 & 0,15 & 0,17 \\
Dev Pad - Divida / Valor de Merc & 0,22 & 0,23 & 0,20 & 0,26 \\
Stat-t - Divida / Ativo & 5,31 & $-3,96$ & - & - \\
Stat-t -Divida / Valor de Mercado & $-3,41$ & $-1,27$ & - & - \\
\hline
\end{tabular}




\section{Tabela 8: Regressão da estrutura de capital com dummy do governo}

Amostra de empresas não financeiras da B3 de 2003 a 2017, regressão (1) de primeiro estágio em MQO e regressão (2) do segundo estágio com variável instrumental. As variáveis independentes estão defasadas de um período com relação ao endividamento, e dummies de período, intercepto e efeitos fixos de firma foram omitidos. Significâncias $* \mathrm{p}<0.1 ; * * \mathrm{p}<0.05 ; * * * \mathrm{p}<0.01$

Estimamos a regressão com instrumento introduzindo a interação do risco idiossincrático com a dummy de empresa controlada pelo governo ou que tenham o governo como um dos controladores. Em tese, o governo deve ser menos sensível ao risco idiossincrático que investidores privados. Sendo assim, espera-se que o coeficiente da interação da dummy de governo com o risco idiossincrático seja positivo, o que ocorre de fato para Gov * Vol Idiossincrática, com coeficiente não significativo.

\begin{tabular}{|c|c|c|}
\hline & \multicolumn{2}{|c|}{ Vaviával dependente } \\
\hline & $\begin{array}{c}\text { Divida sobre Ativo } \\
\qquad 7 \\
\text { (1) }\end{array}$ & $\begin{array}{c}\text { Divida sobre Ativo } \\
\qquad \begin{array}{c}n \\
\text { (2) }\end{array}\end{array}$ \\
\hline Log (Vendas.Liq) & $\begin{array}{c}0.009^{4 * 4} \\
(0.003)\end{array}$ & $\begin{array}{c}0.010^{4 * 4} \\
(0.003)\end{array}$ \\
\hline EBIT/Ativos & $\begin{array}{c}-0.232^{+4 *} \\
(0.049)\end{array}$ & $\begin{array}{c}-0.240^{+4 *} \\
(0.050)\end{array}$ \\
\hline AtivoFixo/AtivoTotal & $\begin{array}{l}0.0005 \\
(0.019)\end{array}$ & $\begin{array}{l}-0.003 \\
(0.019)\end{array}$ \\
\hline ValMerc/ValAtivos & $\begin{array}{c}-0.013^{4 *} \\
(0.006)\end{array}$ & $\begin{array}{l}-0.012^{\circ} \\
(0.006)\end{array}$ \\
\hline Govemo & $\begin{array}{l}0.081^{* 4} \\
(0.036)\end{array}$ & $\begin{array}{c}0.063 \\
(0.038)\end{array}$ \\
\hline Vol Idiossincrática & $\begin{array}{c}-0.279 * 46 \\
(0.091)\end{array}$ & $\begin{array}{c}-0.301^{+4.4} \\
(0.090)\end{array}$ \\
\hline Gov * Vol Idiossincrática & & $\begin{array}{c}0.301 \\
(0.212)\end{array}$ \\
\hline Efeitos Fixos & Sim & Sim \\
\hline Observaçôes & 1,485 & 1,485 \\
\hline $\mathrm{R}^{2}$ & 0.740 & 0.739 \\
\hline $\mathrm{R}^{2}$ ajustado & 0.709 & 0.708 \\
\hline Erro pad. residual & $0.086(\mathrm{df}=1327)$ & $0.086(\mathrm{df}=1326)$ \\
\hline \multirow[t]{2}{*}{ Estatistica-F } & 1,485 & 1,485 \\
\hline & $\begin{array}{c}\text { Vol Idiossincrática } \\
\qquad M Q O\end{array}$ & $\begin{array}{l}\text { Vol Idiossincrática } \\
\qquad M Q O\end{array}$ \\
\hline Log (Vendas.Liq) & $\begin{array}{l}-0.001 \\
(0.002)\end{array}$ & $\begin{array}{l}-0.001 \\
(0.002)\end{array}$ \\
\hline EBIT/Ativos & $\begin{array}{l}-0.054^{*} \\
(0.032)\end{array}$ & $\begin{array}{l}-0.046 \\
(0.032)\end{array}$ \\
\hline AtivoFiro/AtivoTotal & $\begin{array}{c}0.033^{* 4 *} \\
(0.012)\end{array}$ & $\begin{array}{c}0.037^{44 *} \\
(0.012)\end{array}$ \\
\hline ValMerc/ValAtivos & $\begin{array}{c}-0.016^{4 *+*} \\
(0.004)\end{array}$ & $\begin{array}{c}-0.017^{4 * *} \\
(0.004)\end{array}$ \\
\hline Govemo & $\begin{array}{l}-0.093 \\
(0.062)\end{array}$ & $\begin{array}{l}-0.047 \\
(0.064)\end{array}$ \\
\hline Vol Idi Indústria & $\begin{array}{c}0.830^{-4 *} \\
(0.048)\end{array}$ & $\begin{array}{c}0.856^{\circ 44} \\
(0.049)\end{array}$ \\
\hline Gov * Vol Idi Indústria & & $\begin{array}{c}-0.259 * 4 \\
(0.101)\end{array}$ \\
\hline Efeitos Fixos & $\operatorname{Sim}$ & $\operatorname{Sim}$ \\
\hline $\mathrm{R}^{2}$ ajustado & 0.684 & 0.686 \\
\hline Estatistica-F & $21.887^{* * *}(\mathrm{df}=171 ; 1476)$ & $21.881^{* * *}(\mathrm{df}=172 ; 1475)$ \\
\hline
\end{tabular}

